\title{
Hydrosedimentological modeling with SWAT using multi-site calibration in nested basins with reservoirs
}

\author{
Modelagem hidrossedimentológica com o SWAT usando calibração multi-local em bacias \\ embutidas com reservatórios
}

\author{
Paulo Rodrigo Zanin ${ }^{1}$, Nadia Bernardi Bonuma ${ }^{1}$ and Claudia Weber Corseuil ${ }^{2}$ \\ ${ }^{1}$ Universidade Federal de Santa Catarina, Florianópolis, SC, Brasil \\ ${ }^{2}$ Universidade Federal de Santa Catarina, Araranguá, SC, Brasil \\ E-mails: paulorzgeo@gmail.com (PRZ),nadia.bonuma@ufsc.br(NBB), cwcorseuil@hotmail.com (CWC)
}

Received: September 18, 2017 - Revised: August 28, 2018 - Accepted: October 08, 2018

\begin{abstract}
Calibration and validation of hydrosedimentological models, usually performed at the outlet of a single basin, does not always correctly represent the hydrosedimentological processes in the different subdivisions of dammed river systems. The aim of this study was to evaluate simple calibration techniques (watershed outlet) and multi-site calibration (watershed outlet and internal reservoirs) with the Soil and Water Assessment Tool - SWAT model, using two nested basins in the southern region of Brazil. Three modeling procedures were analyzed, adjusting the hydrological and sedimentological parameters of the watershed and the reservoirs. It was found that (a) the simplest calibration does not correctly represent the processes in reservoirs; (b) the multi-site calibration provided a better simulation of the hydrosedimentological dynamics of the nested basins; and (c) parameterizations of the SWAT reservoir module have limitations in the context of the study area. The results showed that the multi-site calibration in watershed with reservoirs is more appropriate.
\end{abstract}

Keywords: SWAT model; Multi-site calibration; Reservoirs.

\section{RESUMO}

A calibração e validação de modelos hidrossedimentológicos, geralmente realizada na saída de uma única bacia, nem sempre representa de forma satisfatória os processos hidrossedimentológicos decorrentes nas diferentes subdivisões de sistemas fluviais represados. O objetivo do presente estudo foi avaliar as técnicas de calibração simples (saída da bacia hidrográfica) e multi-local (exutório da bacia hidrográfica e reservatórios internos) do balanço hídrico e sedimentológico em duas bacias embutidas com o modelo Soil and Water Assessment Tool-SWAT. Foram analisados três procedimentos de modelagem, ajustando os parâmetros hidrológicos e sedimentológicos da bacia hidrográfica e dos reservatórios. Verificou-se que (a) a calibração simples não representou corretamente os processos nos reservatórios; (b) a calibração multi-local simulou melhor a dinâmica hidrossedimentológica das bacias embutidas; e (c) as parametrizações do módulo de reservatórios do $S W A T$ apresentam limitações no contexto da área de estudo. Os resultados mostraram que a calibração multi-local em bacias hidrográficas com reservatórios é mais adequada.

Palavras-chave: Modelo SWAT; Calibração multi-local; Reservatórios. 


\section{INTRODUCTION}

Water, the dynamic component of the hydrosedimentological cycle, is part of the weathering and erosion processes of the rocky and pedological substrate, transporting and depositing sediments through surface runoff and river flow. Therefore, the hydrological cycle is articulated with other matter and energy cycles, and must be analyzed according to the diversity of its components within the system that integrates them, which will present a unique dynamic because of its spatial/temporal magnitude (KLEMES, 1983; BLOSCHL; SIVAPALAN, 1995; TUCCI; MENDIONDO, 1997). According to Tucci (2003), the configurations of the hydrological processes can be classified as 5 magnitudes of spatial scales, which are: microscale $\left(<10^{-4} \mathrm{~km}^{2}\right)$, transition $\gamma\left(10^{-4} \mathrm{~km}^{2}\right.$ to $\left.10 \mathrm{~km}^{2}\right)$, mesoscale $\left(10 \mathrm{~km}^{2}\right.$ to $\left.10^{3} \mathrm{~km}^{2}\right)$, transition $\alpha\left(10^{3} \mathrm{~km}^{2}\right.$ to $\left.10^{4} \mathrm{~km}^{2}\right)$ and macroscale $\left(>10^{4} \mathrm{~km}^{2}\right)$.

In other words, the dominant processes of water flow and sediment yield are different according to the size of the watershed. Therefore it is necessary to take spatial and temporal criteria into account when choosing the best model to represent the hydrosedimentological phenomenon involved (MERRITT; LETCHER; JAKEMAN, 2003). A model that is often used in several parts of the world (GASSMAN et al., 2007), including Brazil (BRESSIANI et al., 2015), is the Soil and Water Assessment Tool - SWAT (ARNOLD et al., 1998, 2012a). This model was developed by researchers from the Agricultural Research Service of the USA (ARS - USDA) and Texas A\&M University. It descends from the Simulator for Water Resources in Rural Basins - SWRRB model (ARNOLD; WILLIAMS, 1987), receiving significant contributions from the Routing Outputs to Outlet - ROTO (ARNOLD; WILLIAMS; MAIDMENT, 1995b) and QUAL2E (BROWN; BARNWELL JUNIOR, 1987) models. The SWAT model is a semi-distributed, watershed scale model based on processes, operating on a daily or sub-daily time scale. Its objective is to evaluate the impact of climate changes, land use/cover and agricultural management on water and sediment balance, nutrients and pesticides for long periods (ARNOLD et al., 2012a).

According to Melo Neto et al. (2014), the SWAT model is used in watersheds from a micro to a macro scale, and it efficiently shows the heterogeneity of dominant hydrological processes as a function of the spatial scale. However, the literature showed that the traditional form of calibration in the SWAT model still has limitations for representing the spatial-temporal diversity of the processes in watersheds. Temporally, Muleta (2012) and Zhang et al. (2015a) discuss the limitation of the traditional form of calibration to represent streamflow in wet and dry periods, proposing alternative calibrations. Spatially, it was found that while Brighenti, Bonuma and Chaffe (2016) calibrated/validated streamflow in a mesoscale basin, they did not manage to achieve validation at a river gauging station downstream of their basin. Thampi, Raneesh and Surya (2010) and Cho et al. (2013) calibrating/validating streamflow in basins in the order of transition $\alpha$ and mesoscale, respectively, managed to validate the simulation in other nested sub-basins on the same scale. Piniewski and Okruszko (2011), in turn, calibrated/validated the streamflow at 11 different stations of a macroscale basin. However, when they validated the simulations at 12 sites nested in the different sub-basins calibrated, in areas of 355 to $1,657 \mathrm{~km}^{2}$, they only had satisfactory results in the subbasins greater than $600 \mathrm{~km}^{2}$.

Other studies analyzed the spatial calibrations in nested sub-basins. Melo Neto et al. (2014) achieved a good performance for hydrological calibration/validation in a mesoscale basin, on the contrary of what they obtained for the individual calibration of a nested basin on a microscale. On the other hand, when Aragão et al. (2013) analyzed the transposition of calibrated hydrologic and sedimentological parameters between two mesoscale nested basins, they found that the process is efficient when the calibrations made in the smaller basin are transferred to the larger basin, but the same does not occur from the larger basin to the smaller one.

The complexity of transferring information efficiently between different basin scales may be due to the model structure (SIKORSKA; RENARD, 2017), and/or uncertainties originating in the input and evaluation data (KAVETSKI; KUCZERA; FRANKS, 2006). Another factor is the way in which the calibration of parameters is rendered operational over the watershed (ZEIGER; HUBBART, 2016), since Shen et al. (2013) found that the key parameters of SWAT and their variations are different depending on the type of soil and its use in nested basins.

Studies using the SWAT model, that evaluated the efficiency of simple calibrations (only at the mouth of a basin) and multi-site in nested basins (mouths of the main basin and nested sub-basins), such as Qi and Grunwald (2005), Cao et al. (2006), Bekele and Nicklow (2007), Zhang, Srinivasan and Liew (2008), Nairaula et al. (2012), Chiang et al. (2014), Noor et al. (2014), Daggupati et al. (2015), Begou et al. (2016), Zeiger and Hubbart (2016), Shrestha et al. (2016), Eduardo et al. (2016), and Bai, Shen and Yan (2017) achieved a better performance of the model with multi-site calibration, associated with the more realistic representation of the heterogeneity of internal processes of the watershed. These studies aimed mainly at simulating streamflow (9 studies), secondarily streamflow, sediments and nutrients (3) and finally only streamflow and sediments (1), using 2 to 13 (mean 5) sub-basins nested in meso to macroscale basins situated in North America (8), Asia (2), South America (1), Africa (1) and Oceania (1). A few studies also evaluated other approaches to calibration (ZHANG; SRINIVASAN; LIEW, 2010; VIGIAK et al., 2015) and analysis of uncertainties (XIE; LIAN, 2013; ZHANG et al., 2015b), associated with the multi-site calibration of nested basins.

Only 4 of the studies on multi-site calibration described above have reservoirs within their drainage area, and only Vigiak et al. (2015) calibrated their sedimentological parameters without showing details on the hydrological calibration. Considering only simple calibration, many studies with SWAT were performed in basins with the presence of reservoirs, some evaluating the hydrological effect (VAN LIEW; GARBRECHT; ARNOLD, 2003; LINO et al., 2009; WAGNER et al., 2011; ZHANG et al., 2012), sedimentological effect (MISHRA; FROEBRICH; GASSMAN, 2007) and water quality effect (ZHANG et al., 2011) of these structures. The specific evaluation of the SWAT module of reservoirs, with calibration and validation of its parameters, was performed by Vale and Holman (2009), Wu and Chen (2012), and Kim and Parajuli (2014). 
Vale and Holman (2009) calibrated the level of the Bosherston Lakes in the United Kingdom, that are the mouth of the drainage basin of this lake system due to their function of preventing the continental intrusion of seawater. First, these authors calibrated the inflow into the lake system and the groundwater level, and then calibrated the level of the lakes, adjusting the water balance parameters of the drainage basin and of the reservoir module. Wu and Chen (2012) compared 3 water discharge methods from reservoirs in the SWAT model, and only one of them was intrinsic to the model. After calibrating and validating the volume and discharges from the Xinfengjiang reservoir in the south of China, they found that the 3 methods can represent their operational purpose, and that the intrinsic method of SWAT had the worst performance. On the other hand, Kim and Parajuli (2014), after calibrating and validating the inflows into the flood control reservoir of Grenada (Mississipi-USA), calibrated and validated the liquid discharges from this dam and the streamflow from a river gauging station downstream. This led them to conclude that in dammed river systems it is essential to perform a correct calibration of the reservoir module of SWAT.

Multi-site calibration with reservoirs was applied to macroscale watersheds in Asia (ZHANG et al., 2013) and in Europe (VIGIAK et al., 2017). Zhang et al. (2013) performed multi-site calibration with 20 river gauging stations located immediately downstream from the reservoirs and sluices associated with 19 river gauging stations distant (upstream and downstream) from these water damming structures. The adjusted hydrological parameters refer to the intrinsic processes of the watershed, since they used a new water release method based on the reservoirs and sluices in their study area. These authors obtained satisfactory simulations at $74 \%$ of the 39 stations and concluded that the regulation of river discharges with hydraulic structures strongly affects the results of the SWAT model. Vigiak et al. (2017) did not detail the hydrological procedures in the reservoirs but calibrated sediment deposition at 55 of the 114 reservoirs (many of them nested), using river gauging stations immediately downstream from them. In association with another 214 river gauging stations for calibration and 172 for validation, they obtained satisfactory simulations, confirming the function of the reservoirs to retain part of the sediment transported by the rivers.

Aiming to complement the Brazilian and international literature on multi-site and reservoir calibration with the SWAT model, the purpose of the present study was to evaluate simulations with a simple and multi-site calibration of the water and sediment balance, in 2 nested mesoscale basins where there are reservoirs. The scientific contribution of this study is to verify the efficiency of the calibration at the mouth of the watershed, to represent the hydrosedimentological balance of reservoirs located in its drainage area, and also the effects of calibrating the reservoirs in the basin that includes them.

\section{MATERIAL AND METHODS}

\section{Study area}

The area studied is the Rio Preto Watershed - RPW, located in the North of the state of Santa Catarina in southern Brazil, as shown in Figure 1. This basin is a sixth order river basin (STRAHLER, 1957), with an area of $965.8 \mathrm{~km}^{2}$ and concentration

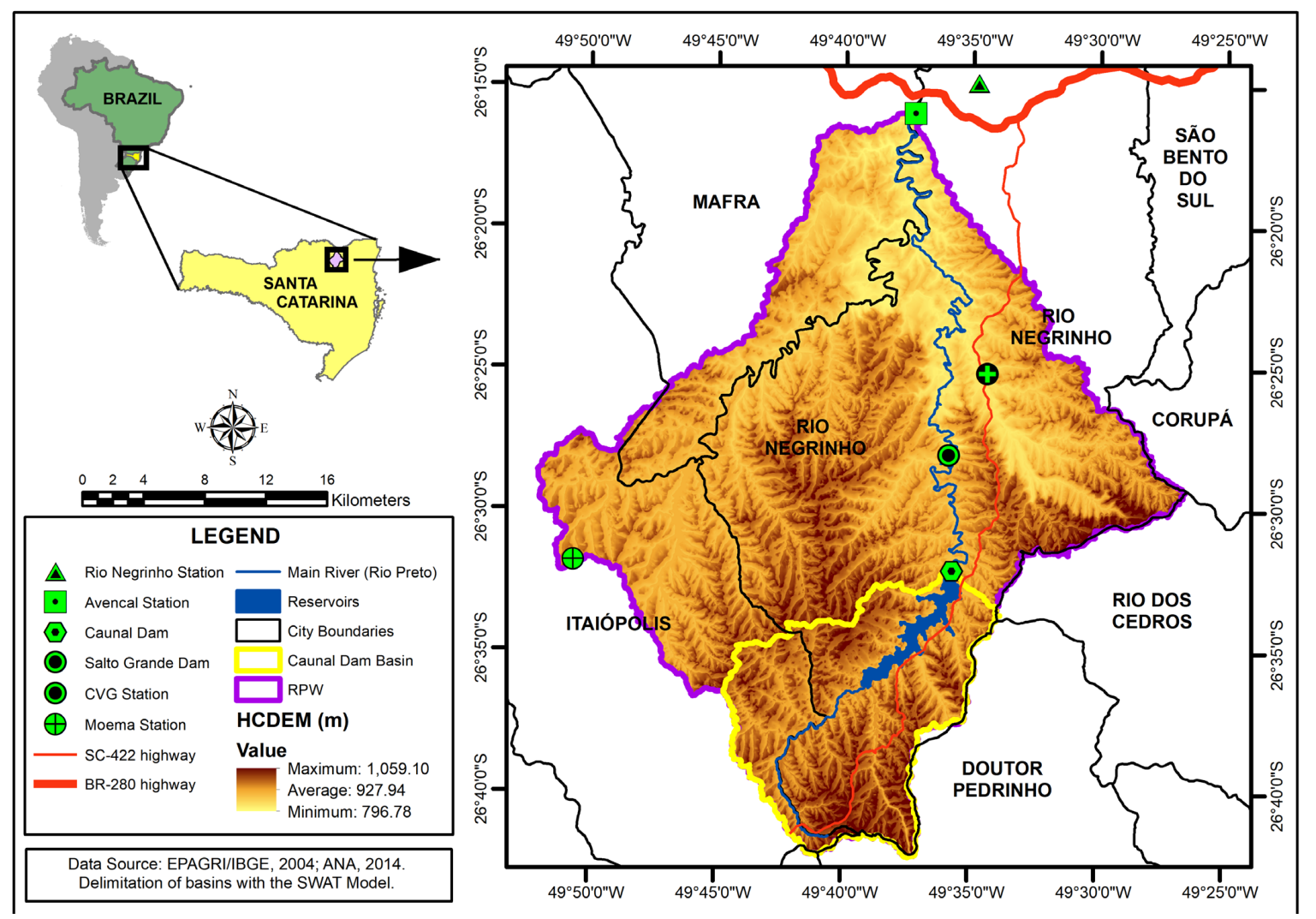

Figure 1. Location of the study area and Hydrographically Conditioned Digital Elevation Model (HCDEM). 
time of 18.98h (DOOGE, 1973). The RPW has 2 representative reservoirs located in one of its 3 fifth order river sub-basins, called Salto Grande Dam, which belongs to a small hydropower plant and the Caunal Dam which is used to regulate the volume of the Salto Grande Dam (Figure 1). Further details on the contributing basin of the Caunal Dam $\left(199.32 \mathrm{~km}^{2}\right)$, that will be analyzed in this study can be obtained in Zanin, Bonuma and Franco (2017).

The climate in the region, according to the Koeppen classification, is $\mathrm{Cfb}$, ie., temperate constantly wet without a dry season and with a cool summer (ALVARES et al., 2013). In the RPW there are sedimentary formations of the volcanic sedimentary basin of Paraná, with porous hydrogeology (CPRM, 2007) and a relief that varies from the steep mountain slopes to gentle hills. Cambisols $(\approx 85 \%)$ and Nitosols $(\approx 12 \%)$ predominate in the basin area, with a less significant occurrence of Latosols $(\approx 2 \%)$ and Neosols $(<1 \%)$. The RPW is a rural basin with land use and land cover that are predominantly forests $(\approx 67 \%)$, with the rest being used for agriculture and pasture $(\approx 32 \%)$, and the presence of water bodies $(\approx 1 \%)$.

The RPW was already modeled by Lino et al. (2009) hydrologically using SWAT. However, modelings validating the streamflow, and also calibration and validation of sediments were not found for the RPW.

\section{Fluviometric data}

In order to evaluate the simple and multi-site calibration of the SWAT model, the mouth defined for the RPW (Figure 1) was the Avencal river gauging station (Cod. 65094500), which is under the responsibility of the Agência Nacional de Águas - ANA and of the Companhia Paranaense de Energia - COPEL. This station has daily records of water level and point data of liquid discharge, sampled between 1976 and 2015. The point data of Suspended Sediment Concentration - SSC were sampled between 1982 and 2014. Since the Caunal Dam broke in 1983 and was rebuilt in 1985, and the Salto Grande Dam was concluded in 1987, all the data on level and flow before 1990 were ignored. Due to the difference in the pattern of the SSC data, before and after the year 2000, the SSC data before this year were also ignored. Since there are gaps in the records of the daily series of levels for a few short periods at Avencal station, it was necessary to fill out the gaps. It should be pointed out that the only period with filled out gaps used to evaluate this modeling was the extreme event that occurred between 7 and 13 June/2014. To fill out the gaps and also to construct the rating curves simple linear regression models were used, validated with the coefficient of determination $\left(\mathrm{R}^{2}\right)$ (MONTGOMERY; RUNGER, 2003). In order to perform these parametric analyses, the data were previously transformed with the base 10 logarithm.

In order to fill out the gaps, the data of the river gauging station of Rio Preto do Sul (Cod. 65095000) were used. It lies $\approx 6 \mathrm{~km}$ downstream from the Avencal station after the river confluence of Rio Preto with Altíssimo Rio Negro. Data from Rio da Várzea dos Lima river gauging station (Cod. 65135000), located $\approx 43 \mathrm{~km}$ north from Avencal station were also used, since it is the only station close to the RPW with records of the maximum event that occurred between 07 and 13 June/2014. Both stations are under the responsibility of ANA/COPEL.

When constructing the regression model between the Avencal and Rio Preto do Sul stations, 4,488 records were used, measured during the period from 01/01/2000 to 06/24/2010. For the model between Avencal and Rio da Várzea dos Lima stations the 16 records referring to the recession of the hydrograph of the extreme event of June 2014 were used. The hydrograph recession data were chosen due to the weak determination of the Rio da Várzea dos Lima station data in relation to the Avencal station data during the period between $01 / 01 / 2000$ and $12 / 31 / 2014$, and the aforementioned extreme rainfall event covered a large space in this region. Thus the behavior of the hydrograph (maximum levels) of these stations originated from the same phenomenon. In order to improve the evaluation of this model, the data simulated and observed for the days from 09/09/2011 to 09/11/2011 were compared. They referred to the peak days of the second largest maximum event that occurred during this modeling period.

The level-flow linear relationship in the RPW was calculated based on 65 records of liquid discharge measurements associated with the respective water level. However, analyzing the level-flow relationship graphically (not shown), it was found that the 3 records were distant from the overall data, and therefore they were eliminated. Moreover, due to the graphic distribution of the data, it was decided to use 2 straight lines of linear adjustment of the data, having the level of $194 \mathrm{~cm}\left(\approx 3^{\circ}\right.$ quartile of the sample) as a threshold, dividing the series into 2 sets of 50 and 12 records. Since one of the straight lines is representative of the 12 highest values sampled, it is then safer to extrapolate the rating curve in relation to the maximum values.

The streamflow-total solid discharge linear relationship was calculated with 38 records of liquid discharge and SSC measurements. First the suspended solid discharges were calculated using Equation 4.7 of Carvalho et al. (2000), and the bottom solid discharge using the simplified method of Colby (1957) in WinTSR software (UFSM), obtaining the total solid discharge by adding up both. Later the regression model between streamflow and total solid discharge was constructed. The streamflow-total solid discharge curve is used due to the absence of linearity between streamflow and SSC in the RPW, and it is employed in hydrosedimentology studies (CARVALHO et al., 2004; FERNANDES et al., 2005; LOPES et al., 2011).

For the continuous series of liquid and solid discharge from the contributing basin of Caunal Dam (reservoir discharge) daily data were used, calculated from the liquid discharge and 20 point data of suspended solid discharge from the study by Zanin, Bonuma and Franco (2017).

\section{SWAT model}

Version 2012 of the SWAT model, revision 627, was used for hydrosedimentological modeling. The input data required by this model are tabular and spatial information representative of the watershed. The spatial data were interpolated or resampled to a spatial resolution of 10 meters, for the purpose of maintaining the same resolution to overlay maps in the definition of the Hydrologic Response Units - HRUs. These maps are: (a) a Hydrographically 
Conditioned Digital Elevation Model (HCDEM); (b) a soil map; and (c) a land use/cover map. Besides the tabular data connected to the maps, SWAT also requires data concerning the characteristics of the channels and dammed water, and also of meteorological variables representing the current climate.

\section{HCDEM}

In the HCDEM (Figure 1), altimetric and hydrographic vectorial data were used, mapped to a scale of 1:50,000 (EPAGRI/IBGE, 2004), utilizing Topo to Raster interpolator (HUTCHINSON, 1988; HUTCHINSON, 1989). It should be emphasized that among the cartographic bases available, the one used in this study best represents the dynamic of potential energy of water and of the balance between release and deposition of debris in the RPW (ZANIN; BONUMA; MINELLA, 2017).

\section{Soil map}

The soil map consisted in editing the base of the Empresa Brasileira de Pesquisa Agropecuária - EMBRAPA (FASOLO et al., 2004), on a scale of detail of 1:250,000. The types of soils in this base were refined up to the second categorical level of the new Brazilian soil classification (JACOMINE, 2009), and later by texture. In this way 7 classes of soils were obtained (Figure 2a).

The tabular data on soils associated with the classes of their respective map, were obtained from primary and secondary sources. The depth (SOL_Z) of the deep soil layer was obtained from the cartographic database of EMBRAPA. The hydrologic group (HYDGRP) (USDA, 1972) of each Brazilian soil was obtained using the classification constructed by Genovez, Lombardi Neto and Sartori (2005). Since SWAT is extremely sensitive to the soil input data (LELIS et al., 2012), a sampling campaign was also performed between 11/04/2014 and 11/08/2014 for the ensemble of soils covered by the basin perimeter, through Uniform Stratified Random Sampling (BARBETTA, 2011), with a sample of each of the 7 classes of soils, according to Figure 2a.

This sampling campaign aimed at obtaining samples of horizons $\mathrm{A}$ and $\mathrm{B}$ (except for Neosol, which only has horizon A) to calculate bulk density (SOL_BD), determine the contents of sand (SOL_SAND), silt (SOL_SILT), and clay (SOL_CLAY), organic carbon (SOL_CBN) and organic matter (needed to calculate USLE_K). The saturated hydraulic conductivity data (SOL_K) and the available water capacity of the soil (SOL_AWC) were estimated using ROSET'TA software (SCHAAP; LEIJ; VAN GENUCHTEN, 2001) based on grain size and bulk density parameters. Albedo (SOL_ALB) was estimated using the Munsell color table. The depth of horizon A of each soil was checked in the field.

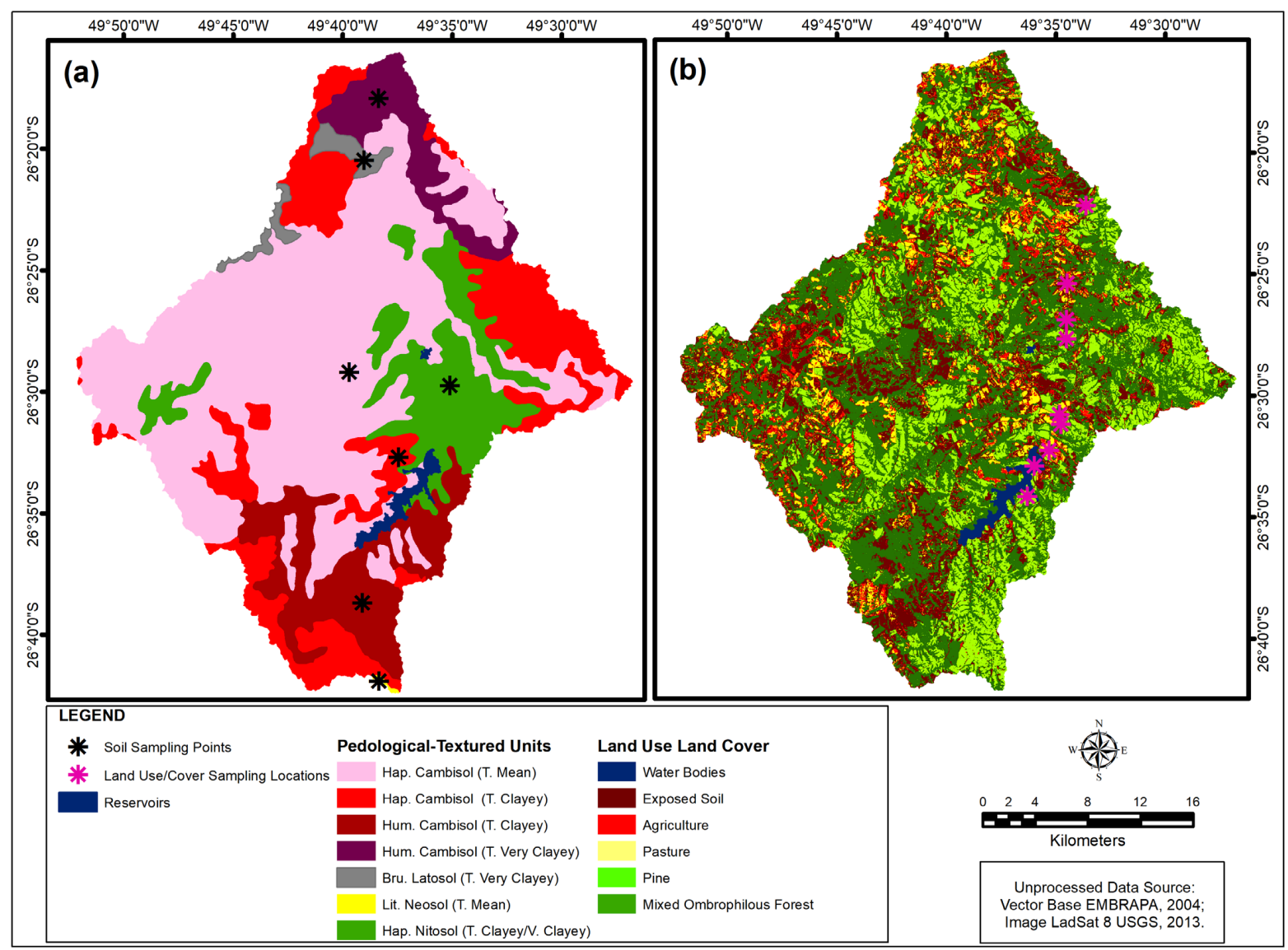

Figure 2. (a) Soil map and pedological sampling points; (b) Land use/cover map and sampling locations for supervised automatic classification. 


\section{Land use/cover map}

A 2013 LandSat 8 image (USGS, 2013) was used to elaborate the land use and land cover map (Figure $2 \mathrm{~b}$ ). Based on this image, and also on verifications in the field between 12/09/2013 and 14/09/2013, homogeneous samples (representative areas) of each class of use and soil cover were identified. Later, a supervised automatic classification was performed using the non-parametric Parallelepiped method as main classifier, and Maximum Likelihood as secondary classifier. The Kappa index was used to evaluate the accuracy of the classification (CONGALTON; GREEN, 1999).

As regards the tabular data associated with the classes in this map, the information provided was as general as possible for agricultural use, due to the uncertainties about the crops planted and agricultural practices used in the basin studied. Only the value for the factor of conservationist practices of MUSLE (USLE_P) was inferred based on the values tabulated by Wischmeier and Smith (1978), due to the existence of plantations on contour lines, and areas of exposed soil used cyclically for agriculture or reforestation.

As to the tabular data on vegetation, the default values of the SWAT model were used due to the great diversity of species that occur the RPW, with scarce data on their characteristics. Based on the literature on the study area and region, it was possible to insert values for the initial biomass (BIO_INI) (SETTE JUNIOR; GEROMINI; NAKAJIMA, 2004; WATZLAWICK et al., 2012) and maximum storage capacity of water in the tree canopy (CANMX) (CHAFFE, 2009; GIGLIO, 2013), for the Mixed Ombrophile Forest (FRST) and Pinus (PINE). As the Manning coefficient $\left(\mathrm{OV} \_\mathrm{N}\right)$ of the FRST class has a default value (0.1) smaller than all the other classes of RPW vegetation, its value was made equal to the PINE class (0.14). However, the value of the initial leaf area index (LAI_INI) for the FRST and PINE classes, had its value inferred to 0.5 due to the fact that the default value is zero.

\section{Channel and base flow data}

The width of the main channel and the tributaries (CH_W) was adjusted with a multiplicative correction factor (0.31) obtained by the ratio between the mean of the widths measured during the period of this modeling (2009 to 2014) at Avencal station by ANA/COPEL, and the width simulated by SWAT. On the other hand, the simulated depths (CH_D) did not require correction since the depth of the channel at the basin mouth was in accordance with the depth observed at the aforementioned station. Therefore it was necessary to correct the width to depth ratio (CH_WDR).

Since the default value for the Manning coefficient (0.014) of the main channel and tributaries (CH_N), is smaller than the values tabulated by Chow (1959) for natural channels, this value was corrected to 0.05 based on field observations performed during this study, in different sectors of the basin. The values of the cover factors (CH_COV) of the banks and bed were also adjusted based on the tabulated values of Julian and Torres (2006). For the bed, which was predominantly soft and without any cover, but with a few hard stretches, the value of the cover factor for the grass-covered bed was used to mitigate the degradation of the channel in areas with a hard bed, but without significantly impairing the processes in the soft bed. The value for sparse trees was utilized for the banks.

The median diameter of the sediment $\left(\mathrm{CH}_{-} \mathrm{D}_{50}\right)$ and the bulk density (CH_BD) of the channel banks and bed materials were estimated based on the data sampled from soils, using the mean weighted by the percentage area of each type of soil. The arithmetic mean of horizons A and B of each soil was used to estimate the diameter of the sediment on the banks, while for bed sediments, the value of the banks was used, arbitrarily increased by $50 \%\left(\mathrm{D}_{50}\right)$, and $25 \%$ (bulk density), due to the fact that the bed received more deposition of coarse material than the banks (HUDSON-EDWARDS, 2007). To define the $\mathrm{D}_{50}$ based on grain size of horizons $\mathrm{A}$ and $\mathrm{B}$, the equation in which SWAT estimates the $\mathrm{D}_{50}$ of sediment flowing into lakes, wetlands and depressions (ARNOLD et al., 2012b) was used to define $\mathrm{D}_{50}$ based on the mean grain size of the horizons $\mathrm{A}$ and $\mathrm{B}$ of each soil. The critical shear stress (CH_TC) of the banks and bed of the channel were estimated using the equation of Julian and Torres (2006), according to Arnold et al. (2012b).

The erodibility of the banks and bed by the jet test (CH_KD) was estimated according to Arnold et al. (2012b). The monthly erodibility factor of the main channel (CH_ERODMO), was estimated based on the mean values of USLE_K of horizons $\mathrm{A}$ and $\mathrm{B}$ of each soil sampled, using the mean weighted by the percentage of area of each type of soil.

As to the base flow, the recession factor of this flow (ALPHA_BF) was calculated with the Base Flow Filter algorithm (ARNOLD et al., 1995a), using the streamflow data from Avencal station observed during the period in which this modeling was performed (2009 to 2014).

\section{Reservoirs data}

Table 1 shows the parameters required by the water release method adopted, and also the respective values used. The data of RES_VOL, RES_PVOL, RES_EVOL, RES_PSA and RES_ESA were obtained using the method of Triangulation with Linear Interpolation, employing bathymetric data surveyed by Lino et al. (2009), and altimetric data on a 1:10,000 scale of the Department of Sustainable Development of the state of Santa Catarina-BR.

For IRESCO the method of Average Annual Release Rate for Uncontrolled Reservoir was chosen, because it was the most appropriate to represent the type of anthropic operation performed in these dams. This method requires the value of RES_RR, referring to the maximum discharge for when the volume is situated among the values defined for the main spillway and the emergency spillway. The amount of water that exceeds the volume of the emergency spillway is released downstream. For the Caunal Dam, the mean of the estimated values of liquid discharge during the period from 2010 to 2014 (ZANIN; BONUMA; FRANCO, 2017), which is close to the $3^{\text {rd }}$ quartile of the flow data, was used. For Salto Grande Dam the Area Weighting method (STEDINGER; VOGEL; FOUFULA-GEORGIOU, 1992) was used, based on the mean of the Caunal Dam flows, due to the scarcity of geometric/structural data on this hydropower plant. 
Table 1. Reservoir parameters and input values.

\begin{tabular}{|c|c|c|c|}
\hline PARAMETER & DESCRIPTION & CAUNAL & SALTO GRANDE \\
\hline MORES & Month in which it becomes operational & Simulation start & Simulation start \\
\hline IYRES & Year in which it becomes operational & Simulation start & Simulation start \\
\hline RES_ESA (ha) & Surface area for RES_EVOL & 897.69 & 37.34 \\
\hline RES_EVOL $\left(10^{4} \mathrm{~m}^{3}\right)$ & Emergency spillway volume & $4,631.69$ & 113.94 \\
\hline RES_PSA (ha) & Surface area for RES_PVOL & 36.33 & 6.29 \\
\hline RES_PVOL $\left(10^{4} \mathrm{~m}^{3}\right)$ & Principal spillway volume & 15.57 & 3.47 \\
\hline RES_VOL $\left(10^{4} \mathrm{~m}^{3}\right)$ & Initial volume & $3,599.72$ & 113.94 \\
\hline RES_SED (mg. $\left.{ }^{-1}\right)$ & Initial sediment concentration & 8.64 & 8.64 \\
\hline RES_NSED $\left(\mathrm{mgll}^{-1}\right)$ & Equilibrium sediment concentration & 8.64 & 8.64 \\
\hline RES_D ${ }_{50}(\mu \mathrm{m})$ & Median sediment diameter & 38.03 & 39.01 \\
\hline RES_K $\left(\mathrm{mm} \cdot \mathrm{h}^{-1}\right)$ & Reservoir infiltration rate & 0.25 & 0.25 \\
\hline EVRSV & Evaporative coefficient & 0.6 & 0.6 \\
\hline IRESCO & Method of reservoir release & 0 & 0 \\
\hline RES_RR $\left(\mathrm{m}^{3} \cdot \mathrm{s}^{-1}\right)$ & Maximum discharge of the principal spillway & 2.73 & 4.12 \\
\hline OFLOWMN_FPS & Minimum discharge as a fraction of RES_PVOL & 0 & 0 \\
\hline
\end{tabular}

For RES_SED and RES_NSED of the reservoirs of both dams, the mean of 20 SSC samplings performed by Zanin, Bonuma and Franco (2017) in the Caunal Dam was used. The value of RES_D ${ }_{50}$ in the Caunal and Salto Grande reservoirs was obtained in the same way as the $\mathrm{D}_{50}$ of the channel banks, considering the area of contribution of each reservoir. For EVRSV the default value (0.6) was used, while for RES_K, which had an amplitude in the model from 0 to $1 \mathrm{~mm} . \mathrm{d}^{-1}$, the value of $0.25 \mathrm{~mm} . \mathrm{d}^{-1}$ was arbitrarily inferred. The zero value was used as OFLOWMN_FPS considering the anthropic regulation of this dam, with an absence of discharge on some days.

\section{Meteorological data}

The daily rainfall data were obtained from 3 rain gauging stations located within the RPW (Figure 1). They are: (a) automatic station CVG, which is under the responsibility of the Companhia Volta Grande de Papel (CVG) and; (b) conventional stations Corredeira (Cod. 2649055) and Moema (Cod. 2649054) under the responsibility of ANA. Although 3 point sources of rainfall data are not highly representative of total rainfall resulting in a $965.8 \mathrm{~km}^{2}$ basin, each of these stations is located in one of the three main sub-basins of the RPW, at altitudes of $845 \mathrm{~m}$ (Corredeira), 880m (CVG) and 950m (Moema).

For the climate generator of SWAT, meteorological data representative of the region were inserted. These data were obtained from the Rio Negrinho meteorological station (Cod. A862 and former code 84), under the responsibility of the Instituto Nacional de Meteorologia (INMET, and formerly the responsibility of EPAGRI/INMET). This station is located close to the basin mouth, as shown in Figure 1, and includes a 22-year time series. Besides filling out the gaps in the rainfall records of the conventional stations, the climate generator was used to simulate the meteorological data necessary to calculate evapotranspiration, because the meteorological station is outside the limits of the RPW.

It should be emphasized that in the case of the gap in the record of the extreme event that occurred in June 2014, it was not completed by the model. In that case, the rainfall that occurred during the event, accumulated and recorded by the conventional stations on the last day of the phenomenon, was redistributed among the days in which the rainfall occurred, proportionally to the records of the CVG automatic station.

\section{Subdivisions of the RPW and main parameterizations}

The criteria of Table 2 were adopted to define micro-basins and HRUs. For the micro-basins, since the level of sub-division affected the simulation of sediment yield (XAVIER et al., 2007), the mean value identified by Fan et al. (2013) as a minimum contribution area for the generation of the hydrography for regions with porous hydrogeology and mean slope greater than $2.5 \%$ was used. After the drainage network was designed by the model, it was visually validated with the hydrography mapped on a scale of 1:50,000 (EPAGRI/IBGE, 2004).

The CN-SCS method (USDA, 1972) was used to calculate the generation of surface runoff, with a value adjusted for slopes greater than 5\% (WILLIAMS, 1995). The Penman-Monteith method (MONTEITH, 1965; ALLEN, 1986; ALLEN et al., 1989) was used to calculate the evapotranspiration. The Muskingum method (BRAKENSIEK, 1967; OVERTON, 1966) was used for water routing in the river channel, considering its degradation, and the Yang Sand and Gravel method (YANG, 1996) for routing sediments in a fluvial environment.

\section{Warm-up, calibration and validation}

For the appropriate warm-up of the model, it is recommended to utilize 2 to 3 years, with calibration and validation being performed in two different sections of the period of data observed, both of them bearing characteristics of wet and dry years. (ARNOLD et al., 2012a). In this way, the model was warmed up during the years of 2009 and 2010, and calibrated for the years of 2011 and 2012, with validation in 2013 and 2014. 
Table 2. Criteria and results for micro-basin and HRUs generation.

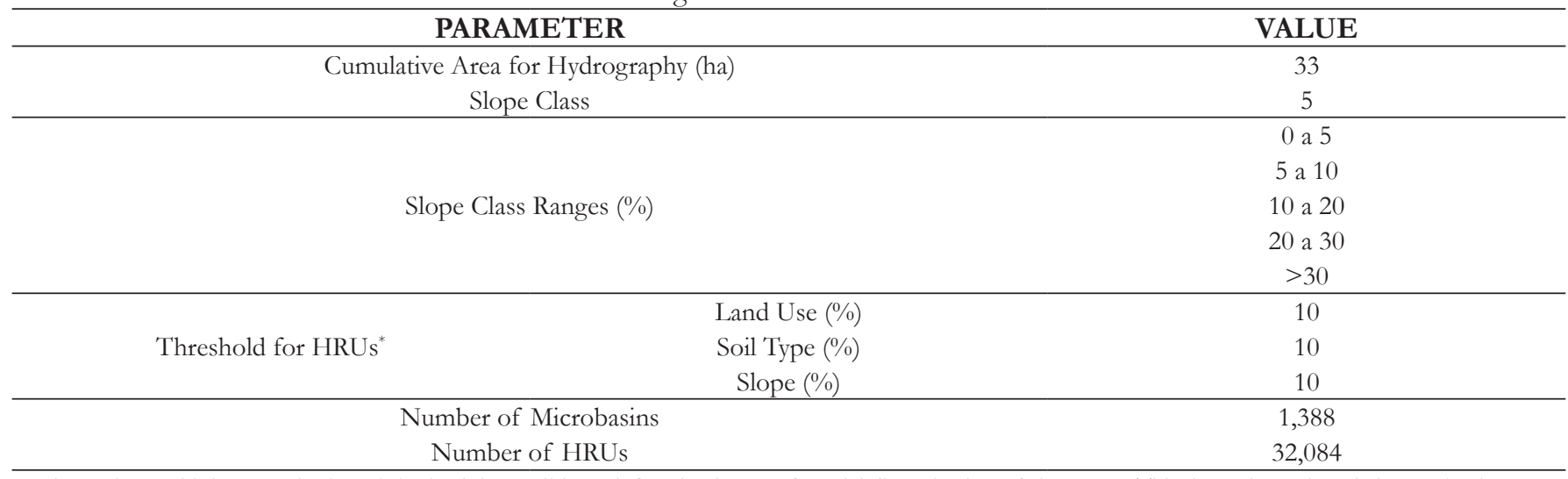

*When using multiple HRUs in the sub-basins it is possible to define the degree of spatial discretization of the HRUs. This depends on the relative or absolute area of land use/cover in relation to the sub-basin area, the soil type over the land use/cover area, and slope over the soil type area.

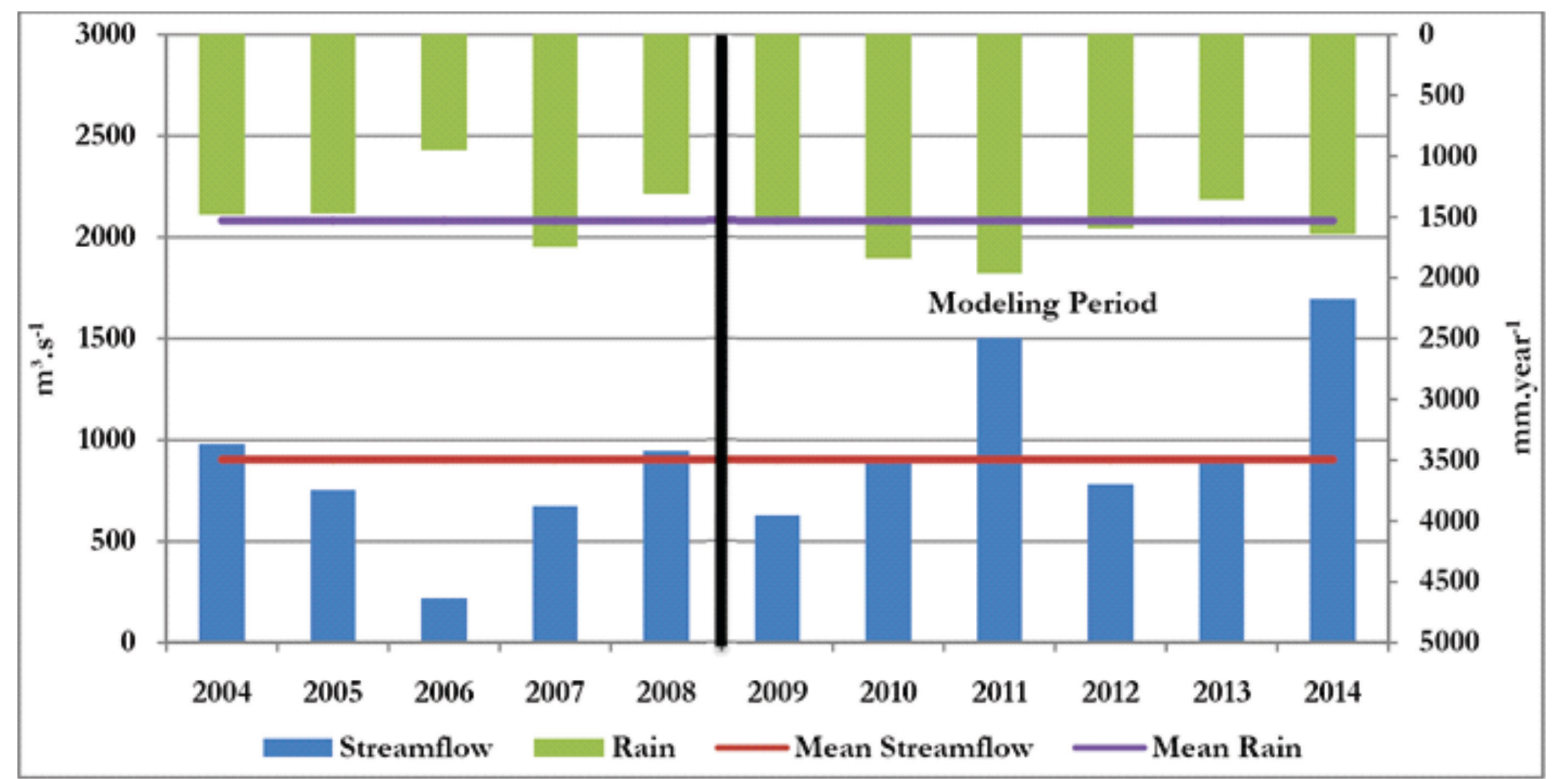

Figure 3. Wet and dry years of the RPW.

Defining a threshold for wet and dry years based on the means of the annual totals of 10 years of liquid discharge and rainfall (Figure 3), it is found that model warm up was performed for a dry year (2009) and a normal to wet year (2010). On the other hand the calibration and validation periods comprise a dry year and a wet year each. Another form of calibration/validation recommended by Arnold et al. (2012a), is to adjust the parameters in a basin and validate them for the same period in another similar basin called Proxy Catchment Test by Klemes (1986).

In order to evaluate the simple and multi-site calibrations, the 3 procedures proposed by Moussa, Chahinian and Bocquillon (2007) were used. The first procedure is the evaluation of the uncalibrated model. In the second the model is calibrated only at the basin river mouth (Avencal station) for a data period (2011-2012), and validated with another data period at the same basin river mouth (2013-2014) and in the sub-basins (Caunal Dam). In the third procedure, multi-site calibration is performed (Avencal station and the dams of Caunal and Salto Grande) for a data period (2011-2012), and validated in another period (2013-2014).

In the second procedure only the parameters referring to the water and sediment processes intrinsic to the watershed, and to the anthropic activities for the management of rural areas were calibrated. To perform the calibration, the base used was (a) the analysis of the water balance obtained in procedure 1, (b) the results of the study by Arnold et al. (2012a), and (c) the calibration values of Lino et al. (2009) (Table 3). The base used to calibrate sediment yield was (a) the analysis of the sediment balance with water balance calibrated in this procedure, and (b) the study by Arnold et al. (2012a) (Table 4). As a complement, other hydrological/sedimentologic studies with SWAT were also used (Table 5).

In the third procedure, the calibration performed previously was maintained, and only the hydrological and sedimentological parameters of the artificial processes occurring in the watershed 
Table 3. Most sensitive SWAT parameters for water balance in 64 modeling studies ascertained by Arnold et al. (2012a), and calibration values of Lino et al. (2009) for the RPW.

\begin{tabular}{cccc}
\hline SURFACE RUNOFF & Lino et al. (2009) & BASE FLOW & Lino et al. (2009) \\
\hline CN2 & $-13 \%$ to $-20 \% ;+2 \%$ & ALPHA_BF & 1 \\
SOL_AWC & $*$ & GW_REVAP & $*$ \\
ESCO & 0 & GW_DELAY & 10 \\
EPCO & $*$ & GW_QMN & $*$ \\
SURLAG & 0 & REVAPMN & $*$ \\
OV_N & $*$ & RCHRD_DP & $*$ \\
\hline
\end{tabular}

*Not calibrated by Lino et al. (2009).

Table 4. Most sensitive SWAT parameters for sediment balance in 64 modeling studies ascertained by Arnold et al. (2012a).

\begin{tabular}{cc}
\hline LANDSCAPE & CHANNEL \\
\hline USLE_P & PRF \\
USLE_C & APM \\
USLE_K & SPEXP \\
LAT_SED & SPCON \\
SLSOIL & CH_EROD \\
SLOPE & CH_COV \\
\hline
\end{tabular}

Table 5. Other parameters with sensitivity and/or calibrated in SWAT modeling studies.

\begin{tabular}{|c|c|c|c|}
\hline PAR. & H. CAL. & L.B. & REFERENCE \\
\hline CANMX & 42 & NB & Malutta (2012); Souza and Santos (2013); Brighenti, Bonuma and Chaffe (2016) \\
\hline BLAI & $43 \%$ & Vietnam & Emam et al. (2016) \\
\hline SOL_K & $900 \%$ & $\mathrm{NB}$; SC & Malutta (2012); Lubitz, Pinheiro and Kaufmann (2013) \\
\hline CH_N & $141 \%$ & USA; BV & Tuppad et al. (2010); Brighenti, Bonuma and Chaffe (2016) \\
\hline MSK_CO1 & $1,100 \%$ & Africa & Schuol and Abbaspour (2006) \\
\hline MSK_CO2 & $2,300 \%$ & & \\
\hline CH_COV1 & $0.6^{*}$ & USA; SF & Tuppad et al. (2010); Creech et al. (2015) \\
\hline SOL_BD & & ** & Lenhart et al. (2002) \\
\hline CHBNK_D ${ }_{50}$ & 500 & USA; SF & Jeong et al. (2011); Creech et al. (2015) \\
\hline CHBED_D & 500 & & \\
\hline CHBNK_KD & 0.1 & SF; Iran & Creech et al. (2015); Garizi and Talebi (2016) \\
\hline CHBED_KD & 1.0 & & \\
\hline CHBNK_TC & 200.6 & SF; Iran & Creech et al. (2015); Garizi and Talebi (2016) \\
\hline CHBED_TC & 257.4 & & \\
\hline
\end{tabular}

The percentages refer to the difference between the initial value and the calibrated value in relation to the initial value. The absolute values refer to the value added when the initial value is zero. PAR. $=$ Parameter; H. CAL. = Higher Calibration among the referenced studies; L.B. = Location of the Basin; NB: Neighboring Basin of the RPW; SC. = state of the Santa Catarina-BR; SF = São Francisco watershed; *The CH_EQN used in the studies cited used CH_COV1,2 with a range of 0-1, different from the present study; **Sensitivity analysis in artificial basin.

were adjusted. These refer to the reservoirs of the Caunal and Salto Grande dams. Since Caunal Dam was the only one with observed hydrosedimentological data, it was used for evaluation. For the Salto Grande Dam the calibrations performed in the dam evaluated were repeated, because the initial values of the more uncertain parameters had been copied or extrapolated from the Caunal Dam. The base used to perform the calibration was (a) analysis of the water and sediment balance of the Caunal Dam obtained in procedure 2, and (b) other modeling studies with SWAT (Table 6).

Green and Van Griensven (2008) recommend the combination of the manual calibration with automatic calibration in the SWAT model. However, it was decided to use only manual calibration in this study. This choice was due to the physical peculiarities of the watershed, which can only be identified by the hydrologist (GREEN; VAN GRIENSVEN, 2008; LUBITZ; PINHEIRO; KAUFMANN, 2013; MELO NETO et al., 2014; BROUZIYNE et al., 2017). According to Tucci and Collischonn (2003), for a user experienced in hydrological modeling, manual calibration is a relatively simple stage that implicitly takes multiple objectives into account. These authors also found that the results obtained with automatic multi-objective calibration are equivalent to those obtained with a good, detailed manual calibration. In agreement with these authors, it was found that in the results of Sloboda and Swayne (2013) the hydrological simulations with SWAT utilizing manual calibration have the same level of efficiency as the simulations 
Table 6. SWAT reservoir module parameters with sensitivity and/or calibrated in modeling studies.

\begin{tabular}{cccc}
\hline PAR. & H. CAL. & L.B. & REFERENCE \\
\hline RES_K & 4.0 & United Kingdom; China; EUA & Vale and Holman (2009); Wu and Chen (2012); Kim and Parajuli (2014) \\
RES_SED & $99.9 \%$ & SF & Creech et al. (2015); \\
RES_NSED & $99.9 \%$ & USA; SF; ES. & Wu and Liu (2012); Creech et al. (2015); Guimarães (2016); Vigiak et al. (2017) \\
RES_D & $22 \%$ & Poland & Marcinkowski et al. (2013) \\
\hline
\end{tabular}

Only the hydrological parameters used in the IRESCO=O. With the exception of Vigiak et al. (2017), the sedimentological studies carried out the evaluation in fluviometric station distant from the dam. ES. = state of the Espírito Santo-BR; Other acronyms are equal to Table 5.

calibrated with the main algorithms of SWAT-CUP. The only significant difference found by these authors was the time of execution. On the other hand, Melo Neto et al. (2014) identified manual calibration as more efficient than automatic calibration. These authors found a cascade effect of incoherent values in the automatic calibration process, where one parameter compensates for the other, generating simulations with values close to the real ones, but without representing the dominant physical processes in the basin. It should be underscored that some SWAT users have been choosing only manual calibration in recent years, obtaining satisfactory simulations (LUBITZ; PINHEIRO; KAUFMANN, 2013; BROUZIYNE et al., 2017). In this way it was found that the great advantage of automatic calibration is that it saves time, while manual calibration is essential to ensure the appropriate representation of the physical processes in the watershed. The use of automatic calibration, restricted to a small amplitude around the manually calibrated values, would probably result in a slight gain in the statistical indices. However, since the objective of this study is to evaluate the simple and multi-site calibrations in the watershed, manual calibration was sufficient to compare the different procedures that are being analyzed.

In the manual calibration process, the different parameters were adjusted individually and cumulatively, and the changes in the values were done similarly with the analysis of manual sensitivity by Lubitz, Pinheiro and Kaufmann (2013). In other words, each of the parameters identified in the literature was altered at constant intervals (generally $5 \%$ ) on their initial values, until the best calibration was obtained. The range of the adjustments was limited arbitrarily, according to the uncertainties contained in the initial value of each parameter.

Different evaluation metrics were used to assess the efficiency of the simulations, aiming to verify the performance of the model in different parts of the hydrograph. For peak events, the index of Nash and Sutcliffe (NSE) (NASH; SUTCLIFFE, 1970) and the coefficient of determination $\left(\mathrm{R}^{2}\right)$ (MONTGOMERY; RUNGER, 2003) were used, since they are more influenced by the maximum values (MORIASI et al., 2007). The Mean Absolute Error (MAE) was used for mean values, showing the central tendency value of the error in simulation in the same units as the data observed, and the Percentage Bias (PBIAS), which enables evaluating the mean tendency of the simulated volumes (MORIASI et al., 2007). For the minimum events, the LogNSE index was used, which is applied in hydrology studies for this purpose (SOUZA; SANTOS, 2013).

Although the developers of the SWAT model (ARNOLD et al., 2012a) consider daily simulations of streamflow and sediments with values $\geq 0.5$ and 0.6 for NSE and $R^{2}$, respectively, acceptable, this study adopted other individual criteria for each basin.
In the $6^{\text {th }}$ order river basin, the criterion of Green et al. (2006) was adopted. They considered satisfactory daily simulations in SWAT with values $\geq 0.4$ and 0.5 for NSE and $R^{2}$, respectively, in a predominantly rural basin on a mesoscale $\left(580.5 \mathrm{~km}^{2}\right)$. On the other hand, for the reservoir that is the mouth of the $5^{\text {th }}$ order river basin, the criterion of Kim and Parajuli (2014) was adopted. When they evaluate the module of SWAT reservoirs in the daily time step, they consider values of NSE and $\mathrm{R}^{2} \geq 0.3$ acceptable. The choice of these values is justified for the indices mentioned for the following reasons: a) there are two representative reservoirs in the main river of the RPW, and this limits the efficiency of the hydrological simulations of the SWAT model (ZHANG et al., 2013), reducing the inter-annual sedimentological variability in dammed rivers (VIGIAK et al., 2017); b) Wu and Chen (2012) calibrating the daily liquid discharge in 3 methods of release from reservoirs in the SWAT model, obtained an NSE of 0.13 to 0.36 and correlation coefficient (r) of 0.36 to 0.60 during the calibration period, with smaller values during the validation period; and c) the aforementioned criteria meet the objective of evaluating different modeling procedures in nested basins.

For PBIAS, Moriasi et al. (2007) recommend values of $< \pm 25 \%$ and $< \pm 55 \%$ for streamflow and sediments, respectively, in monthly simulations on watersheds. Thus, for the daily time step, and considering also the analysis of reservoirs, in this study values of $< \pm 30 \%$ for streamflow and $< \pm 60 \%$ for sediments will be considered valid. For MAE, Moriasi et al. (2007 and references therein) consider values less than $50 \%$ of the standard deviation of the data observed.

According to a recommendation by Zeiger and Hubbart (2016), first the liquid discharge was calibrated and then the solid discharge, because the hydrological processes were dominant in sediment yield (VAN GRIENSVEN et al., 2006). Aiming to perform a more realistic calibration of the water balance, as per the recommendation by Yu and Schwartz (1999), together with the total runoff, the surface runoff and base flow were also evaluated. These were obtained by separating the runoff with the Base Flow Filter algorithm (ARNOLD et al., 1995a).

As to the sedimentological calibration, the channel parameters present the greatest uncertainties (ARNOLD et al., 2012a). Moreover, if the Yang Sand and Gravel method is used, the parameterizations of the channels are even more influential in the production of sediments than those of landscape (JEONG et al., 2011). Nevertheless, the input of sediments to the channels affects the fluvial sedimentological processes, since it directly influences the SSC (HUDSON-EDWARDS, 2007 and references therein). Thus, first the parameters referring to landscape processes were calibrated and then those of the channels. 


\section{RESULTS AND DISCUSSION}

\section{Fluviometric data}

When filling out the gaps in the water level records of Avencal station, the regression model used based on the data from Rio Preto do Sul station obtained an $\mathrm{R}^{2}$ of 0.53 . The periods in which gaps were filled out with this regression model were only used in Figures 3 and 4. On the other hand, the regression model based on data from the Rio da Várzea dos Lima station obtained an $\mathrm{R}^{2}$ of 0.73 and overestimates on average $29 \%$ of the data observed. Only this model was used to complete the gaps in the evaluation period of this modeling, more precisely, the days of the peaks of the extreme event in June/2014. The level-streamflow rating curves of the RPW, defined for the levels below and above $194 \mathrm{~cm}$, have an $\mathrm{R}^{2}$ of 0.80 and 0.88 , respectively. The rating curve of total solid discharge from this basin, on the other hand, obtained an $\mathrm{R}^{2}$ of 0.90 .

Figure 4 shows the SSC sampling campaigns on the hydrograph of Avencal station, and the limit of extrapolation of the streamflow rating curve. It is observed that during the period from 2000 to 2014, the streamflow rating curve was only extrapolated in a few minimum extreme events, and in most of the maximum extreme events. However, the SSC sampling campaigns were performed predominantly during flows with intermediate magnitudes, with few samplings during extreme events. Based on the hydrograph events, it was found that the 38 SSC sampling campaigns covered all its moments, and most of the samples are located in the recession (17 records) and rise (9 records) of the hydrograph, and there are also 7 samplings over the valley and 5 samplings over streamflow peaks. For the Caunal Dam, the liquid discharge-suspended solid discharge rating curve has an $\mathrm{R}^{2}$ of 0.95 . The SSC samplings on the hydrograph of this dam, and also their classification by event, may be verified in Zanin, Bonuma and Franco (2017).

\section{$1^{\circ}$ Modeling procedure: initial simulation}

According to Table 7 , the initial simulation was not satisfactory for the RPW and the Caunal Dam. This is due to the poor performance of the base flow, resulting in a streamflow equal to $0 \mathrm{~m}^{3} \cdot \mathrm{s}^{-1}$ on some days of the simulated hydrograph (not shown). In the PBIAS values except for the surface runoff during the calibration period, all runoffs were underestimated in both periods in the RPW. In the Caunal Dam, the simulations overestimate the data observed.

Although the hydrological simulation was not satisfactory, the sediment yield simulation was examined (Table 8). As expected, the simulations were not satisfactory in both basins. For the RPW, while the sediment yield is overestimated in the first period of evaluation, it is underestimated in the second period. But in Caunal Dam it is underestimated in both periods.

\section{$2^{\circ}$ Modeling procedure: simple calibration}

The calibration of the RPW water balance aimed to reduce the water losses, increasing base flow. Table 3 shows that the parameters identified by Lino et al. (2009) as the most influential in the RPW water balance corroborate the study by Arnold et al. (2012a). Nevertheless, observing the values used in the calibration by Lino et al. (2009), it was found that the base flow recession constant (ALPHA_BF) and the surface runoff lag coefficient (SURLAG) do not represent the physical characteristics of the RPW, since the value of ALPHA_BF equal to 1 (1 day) is much lower than the value of 0.0313 (approx. 40 days) calculated based on observed RPW streamflow data. Likewise, a SURLAG value equal to zero indicates that no fraction of the surface runoff reaches the main channel on the day when it is generated, which is not compatible with the concentration time of $18.98 \mathrm{~h}$ of the RPW.

The need for excessive adjustment of the SWAT parameters, to render the simulated data compatible with the observed data, forcing the simulation of the physical processes in the model,

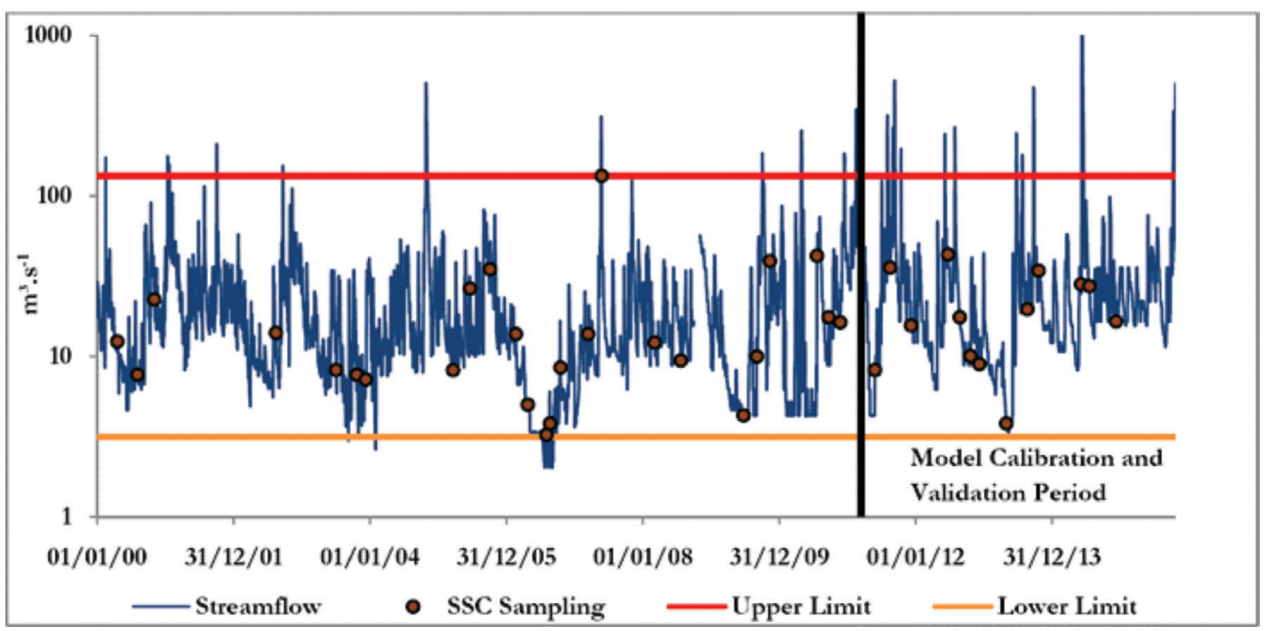

Figure 4. Hydrograph of the Avencal station (RPW) with the limits of extrapolation of level-streamflow rating curve, and SSC sampling campaigns. Daily time scale. Source of point data: ANA/COPEL. 
Table 7. Statistical indices of the three hydrological modeling procedures.

\begin{tabular}{|c|c|c|c|c|c|c|c|c|c|c|c|}
\hline \multirow{2}{*}{$\mathbf{P}$} & \multirow{2}{*}{ FLOW } & \multicolumn{5}{|c|}{ AVENCAL } & \multicolumn{5}{|c|}{ CAUNAL } \\
\hline & & NSE & $\mathbf{R}^{2}$ & PBIAS & MAE & LogNSE & NSE & $\mathbf{R}^{2}$ & PBIAS & MAE & LogNSE \\
\hline \multicolumn{12}{|c|}{$1^{\circ}$ PROCEDURE (INITIAL SIMULATION) } \\
\hline \multirow[t]{3}{*}{$\mathrm{C}$} & BF. & -0.01 & 0.38 & 62.78 & 15.05 & -7.47 & - & - & - & - & - \\
\hline & SR. & 0.59 & 0.17 & -0.59 & 9.26 & 0.47 & - & - & - & - & - \\
\hline & TF. & 0.54 & 0.41 & 42.31 & 18.62 & -2.35 & 0.19 & 0.26 & -59.69 & 3.10 & -0.06 \\
\hline \multirow[t]{3}{*}{ V } & BF. & 0.00 & 0.28 & 79.91 & 19.28 & -15.85 & - & - & - & - & - \\
\hline & SR. & 0.46 & 0.06 & 47.50 & 13.86 & 0.49 & - & - & - & - & - \\
\hline & TF. & 0.38 & 0.26 & 67.14 & 29.21 & -6.44 & 0.91 & 0.02 & -65.85 & 1.81 & -0.29 \\
\hline \multicolumn{12}{|c|}{$2^{\circ}$ PROCEDURE (SIMPLE CALIBRATION) } \\
\hline \multirow[t]{3}{*}{$\mathrm{C}$} & $\mathrm{BF}$ & 0.62 & 0.78 & 31.12 & 8.25 & 0.10 & - & - & - & - & - \\
\hline & SR. & 0.57 & 0.30 & 0.86 & 8.99 & 0.58 & - & - & - & - & - \\
\hline & TF. & 0.62 & 0.75 & 21.34 & 13.63 & 0.57 & 0.02 & 0.32 & -96.77 & 4.06 & -0.29 \\
\hline \multirow[t]{3}{*}{$\mathrm{V}$} & $\mathrm{BF}$. & 0.24 & 0.50 & 57.25 & 14.33 & -0.95 & - & - & - & - & - \\
\hline & SR. & 0.50 & 0.13 & 41.27 & 13.29 & 0.55 & - & - & - & - & - \\
\hline & TF. & 0.46 & 0.53 & 50.95 & 24.32 & 0.19 & 0.67 & 0.00 & -124.94 & 2.76 & -0.46 \\
\hline \multicolumn{12}{|c|}{$3^{\circ}$ PROCEDURE (MULTI-SITE CALIBRATION) } \\
\hline \multirow[t]{3}{*}{$\mathrm{C}$} & $\mathrm{BF}$. & 0.57 & 0.76 & 35.85 & 9.03 & -0.08 & - & - & - & - & - \\
\hline & SR. & 0.57 & 0.29 & 5.38 & 8.80 & 0.57 & - & - & - & - & - \\
\hline & TF. & 0.61 & 0.74 & 26.00 & 13.93 & 0.50 & 0.30 & 0.30 & -43.12 & 2.77 & 0.02 \\
\hline \multirow[t]{3}{*}{ V } & BF. & 0.21 & 0.46 & 60.85 & 14.98 & -2.55 & - & - & - & - & - \\
\hline & SR. & 0.47 & 0.14 & 45.60 & 13.35 & 0.55 & - & - & - & - & - \\
\hline & TF. & 0.43 & 0.45 & 54.84 & 24.97 & -0.53 & 0.86 & 0.04 & -41.62 & 1.41 & -0.09 \\
\hline
\end{tabular}

Values within the adopted criteria are highlighted. $\mathrm{C}=$ Calibration (2011-2012); V = Validation (2013-2014); BF. = Base Flow; SF. = Surface Runoff; TF. = Total Flow (Streamflow); P=Period.

Table 8. Statistical indices of the three sedimentological modeling procedures.

\begin{tabular}{|c|c|c|c|c|c|c|c|c|c|c|}
\hline \multirow{2}{*}{$\mathbf{P}$} & \multicolumn{5}{|c|}{ AVENCAL } & \multicolumn{5}{|c|}{ CAUNAL } \\
\hline & NSE & $\mathbf{R}^{2}$ & PBIAS & MAE & LogNSE & NSE & $\mathbf{R}^{2}$ & PBIAS & MAE & LogNSE \\
\hline \multicolumn{11}{|c|}{$1^{\circ}$ PROCEDURE (INITIAL SIMULATION) } \\
\hline $\mathrm{C}$ & -0.02 & 0.30 & -173.12 & 937.21 & -0.94 & 0.03 & 0.30 & 82.97 & 2.49 & -0.27 \\
\hline $\mathrm{V}$ & 0.45 & 0.22 & 24.97 & 833.12 & -1.38 & 0.10 & 0.01 & 73.56 & 1.51 & 0.13 \\
\hline \multicolumn{11}{|c|}{$2^{\circ}$ PROCEDURE (SIMPLE CALIBRATION) } \\
\hline $\mathrm{C}^{*}$ & -0.03 & 0.67 & -187.54 & 937.84 & 0.11 & 0.03 & 0.36 & 79.64 & 2.48 & -0.24 \\
\hline $\mathrm{C}$ & 0.49 & 0.69 & -37.94 & 434.07 & 0.63 & 0.03 & 0.35 & 79.66 & 2.48 & -0.24 \\
\hline $\mathrm{V}$ & 0.47 & 0.44 & 45.97 & 681.45 & 0.71 & 0.11 & 0.00 & 72.78 & 1.49 & 0.16 \\
\hline \multicolumn{11}{|c|}{$3^{\circ}$ PROCEDURE (MULTI-SITE CALIBRATION) } \\
\hline $\mathrm{C}$ & 0.48 & 0.71 & -42.07 & 453.86 & 0.61 & 0.30 & 0.34 & 1.01 & 2.09 & 0.17 \\
\hline $\mathrm{V}$ & 0.47 & 0.43 & 45.81 & 668.68 & 0.64 & -0.25 & 0.03 & 43.17 & 3.46 & -0.28 \\
\hline
\end{tabular}

Values within the adopted criteria are highlighted. C = Calibration (2011-2012); C* = Hydrological calibration only; V = Validation (2013-2014); P=Period.

was already found by Lubitz, Pinheiro and Kaufmann (2013) and Melo Neto et al. (2014). Therefore, the calibration by Lino et al. (2009) was considered only for the identification of the more sensitive parameters.

Since the simulation of surface runoff, except for $\mathrm{R}^{2}$, was satisfactory for the other indices for the $1^{\text {st }}$ procedure (Table 7), it was not necessary to perform a calibration using the coefficient of generation of surface runoff for the condition of mean moisture of the soil (CN2). Besides, since the shape of the simulated hydrograph is in accordance with the shape of the observed hydrograph (Not shown), it was not necessary to adjust the Manning value for overland flow (OV_N) and the SURLAG. The parameter ALPHA_BF was also not adjusted, since its initial value was extracted from the observed hydrograph.
Aiming to reduce water losses to the atmosphere, the compensation factor of evaporation from the soil (ESCO) was increased to the maximum, since in this way only the surface layer of the soil meets the evaporative demand of the low troposphere. The compensation factor of water uptake from soil by the plants (EPCO) was not sensitive to calibration, which is due mainly to the fact that the root zone is comprised of the entire soil profile. The reduction of EPCO, associated with the reduction of the root zone or with the increased soil depth, did not improve the simulation in any way. The water content available to plants (SOL_AWC) was reduced by $50 \%$, diminishing plant transpiration. Besides these parameters, the value of maximum canopy storage of plants (CANMX) and the maximum leaf area index (BLAI) were reduced by $25 \%$ and $50 \%$, respectively. 
To increase the base flow, the delay time of groundwater flow (GW_DELAY) was reduced to half of the value calibrated by Lino et al. (2009), associated with the $75 \%$ reduction of the water threshold in the shallow aquifer for the occurrence of base flow (GW_QMN). The water fraction that percolates from the shallow aquifer to the deep aquifer (RCHRG_DP), was also reduced. Due to the porous hydrogeology of the RPW (CPRM, 2007), it was considered arbitrarily that the minimum acceptable value was $2 \%$.

The capillary rise coefficient of water in soil (GW_REVAP), and the water threshold in the shallow aquifer for the water rise to occur (REVAPMN), were not sensitive to calibration. To make it easier to infiltrate into the soil and increase the groundwater flow, the saturated hydraulic conductivity of soils (SOL_K) was increased by $25 \%$.

In order to correct the absence of streamflow on some days, the Manning coefficient (CH_N) was reduced by $40 \%$, increasing the flow rate. Since CH_N is based on the channel cover, it was considered necessary to also reduce the cover factor of the banks (CH_COV1) and bed (CH_COV2), since these parameters affect the degradation of the channel and consequently river flow.

The calibration coefficients of the normal (MSK_CO1) and minimum (MSK_CO2) flow storage time constant of the Muskingum method, were raised to 2 and 10, respectively. In this way the storage time of the constant value along the different channel segments increased. Table 9 presented a summary of the water balance calibration performed in this procedure.

The simulation of total flow was satisfactory with the aforementioned calibration, according to Table 7 . This is due mainly to the significant improvement of the base flow that, although not yet satisfactory, achieved better values in all metrics, with three acceptable indices. The surface runoff was maintained with acceptable values in four indices, improving the values of three of the five metrics.

In the validation period, the simulation of total flow was not satisfactory, despite the significant improvement in relation to the initial simulation. The streamflow simulated in this period obtained three acceptable indices, and was not accepted because of strong underestimation, due to the poor representation of the minimum flows, according to the values of PBIAS and LogNSE.

Once the total flow has been calibrated, Table 8 shows that the simulation of sediment yield is unsatisfactory in the RPW. Since the value of PBIAS is strongly overestimated the sedimentological calibration aimed at reducing the estimate of erosive processes in the RPW. The factor of conservationist practices of MUSLE (USLE_P) in areas with agriculture and exposed soil, was reduced by $50 \%$, confirming the minimum values tabulated by Wischmeier and Smith (1978). The minimum value of the water erosion factor based on soil cover (USLE_C) was reduced by $50 \%$ for agriculture and exposed soil, due to lack of knowledge regarding the types and amounts of crops cultivated in the RPW. It was also necessary to reduce the soil erodibility factor of the MUSLE (USLE_K) by 25\%.

As to the sediment concentration in lateral and groundwater flow (LAT_SED), its default value is already the minimum (value 0). However the length of the lateral ramp for the sub-surface flow (SLSOIL), as well as the mean slope (SLOPE), were extracted directly from HCDEM by SWAT model, and therefore they were not adjusted. The bulk density of the soils (SOL_BD) was reduced by $25 \%$.

The adjustment factor of sediment transport with the peak flow in the main channel (PRF) did not present sensitivity in calibration. The default value of the same factor for tributary channels (APM or ADJ_PKR) was reduced by 50\%. This calibration is due to the absence of linearity between SSC and streamflow in the data from Avencal station. The linear (SPCON) and exponential (SPCON) coefficients of Bagnold's sediment transport were not altered since this method was not utilized in this modeling. The monthly erodibility parameter of the channel (CH_EROD) did not present sensitivity, as occurred with Lubitz, Pinheiro and Kaufmann (2013). As to the parameter of banks and bed cover (CH_COV), this has already been adjusted in the calibration of liquid discharge.

The $\mathrm{D}_{50}$ of the banks (CH_BNK_D ${ }_{50}$ ) and bed (CH_BED_D $\left.{ }_{50}\right)$ was increased by $25 \%$. On the other hand, the bulk density of the banks (CH_BNK_BD) and bed (CH_BED_BD) was reduced by $25 \%$. The critical shear stress values of the banks (CH_BNK_TC)

Table 9. Manual calibration of the RPW water balance.

\begin{tabular}{|c|c|c|c|c|}
\hline PARAMETER & INITIAL VALUE & OPERATION & OPERATION VALUE & FINAL VALUE \\
\hline ESCO & 0.95 & Replacement & 1 & 1 \\
\hline SOL_AWC & Several & Multiplication & 0.50 & Several \\
\hline \multirow[t]{2}{*}{ CANMX } & 3.40 FRST & Multiplication & 0.75 & 2.55 \\
\hline & 2.71 PINE & & & 2.0325 \\
\hline BLAI & Several & Multiplication & 0.50 & Several \\
\hline GW_DELAY & 31 & Replacement & 5 & 5 \\
\hline GW_QMN & 1,000 & Multiplication & 0.25 & 250 \\
\hline RCHRD_DP & 0.05 & Multiplication & 0.20 & 0.01 \\
\hline SOL_K & Several & Multiplication & 1.25 & Several \\
\hline $\mathrm{CH} \_\mathrm{N}(1,2)$ & 0.05 & Multiplication & 0.60 & 0.03 \\
\hline CH_COV(1) & 5.40 & Multiplication & 0.60 & 3.24 \\
\hline CH_COV(2) & 1.97 & Multiplication & 0.60 & 1.182 \\
\hline MSK_CO1 & 0.75 & Replacement & 2 & 2 \\
\hline MSK_CO2 & 0.25 & Replacement & 10 & 10 \\
\hline
\end{tabular}


and bed (CH_BED_TC) were increased 4 times. Therefore, the erodibility according to the jet test of the banks (CH_BNK_KD) and bed (CH_BNK_KD), which was estimated based on the critical shear stress, was calculated again based on the calibrated values. These calibrations whose initial value was greatly altered are justified because the initial values are estimated from the bank and bed cover. Table 10 presents a summary of the calibration of sediment yield.

As a result of the calibrations, the sedimentological simulation of the RPW was satisfactory during the calibration period (Table 8). This simulation was not validated only because of the value of $\mathrm{R}^{2}$, which despite being close to the criterion adopted was not satisfactory. It should be pointed out that while the calibration period overestimates the data observed, the validation period underestimates them. When the sediment balance was calibrated, especially the parameter SOL_BD, variations occurred that were smaller than or equal to a unit in the hydrological calibration evaluation indices, and the metrics of acceptable values were maintained in criterion adopted.

Analyzing the simulations of this procedure in the nested basin (Tables 7 and 8), it is found that neither simulation was satisfactory. Except for $\mathrm{R}^{2}$ in the calibration period, the hydrological adjustments in the watershed made the values of the other metrics worse in both evaluation periods. On the other hand, the sedimentological calibration of the RPW slightly improved the values of most metrics of the Caunal Dam. For this reason it was not possible to perform the hydrosedimentological validation by Proxy Catchment Test in the RPW.

\section{$3^{\circ}$ Modeling procedure: multi-site calibration}

The liquid discharge of the Caunal Dam did not show good results in the previous procedures, and the data observed were greatly overestimated (Table 7). Thus, the calibration of the water balance aimed at increasing the water losses in the reservoirs.

The initial value of RES_K was inferred arbitrarily, and was very imprecise. Another parameter full of uncertainties is EVRSV, in which the default value of the model was used. It was thus necessary to increase the value of RES_K by 4.4 times its initial value, associated with the maximum value of EVRSV, to obtain an acceptable water balance.
Another parameter with many uncertainties is RES_VOL. Figure 3 shows that the year the simulation began (2009) was a dry year and the year that the records of Caunal Dam began (2010) was a wet year. The accumulated rainfall (Station CVG) in the previous month $(12 / 2008)$ when the simulation began was $90.4 \mathrm{~mm}$, and the streamflow on the day the simulation began $(01 / 01 / 2009)$ at the mouth of the RPW was $8.57 \mathrm{~m}^{3} \cdot \mathrm{s}^{-1}$. Meanwhile, the value used for RES_VOL (referring to 01/01/2009) in the Caunal Dam was the volume of day $01 / 01 / 2010$, in which the accumulated rainfall of the previous month $(12 / 2009)$ was $158 \mathrm{~mm}$, with a streamflow of $23.47 \mathrm{~m}^{3} \cdot \mathrm{s}^{-1}$ at the mouth of the RPW on the aforementioned day. Thus, in order to render compatible the value of RES_VOL obtained in the wet year (2010) with a more representative value of the dry year (2009), the value of this parameter was reduced by $50 \%$. Another parameter that had to be adjusted was RES_RR, and its reduction by $15 \%$ was justified because the initial value was based on the mean of the daily sample of the liquid discharge from a dam between 2010 and 2014.

As to the Salto Grande Dam, while the Caunal Dam reservoir is located predominantly on Medium Texture Haplic Cambisol (average SOL_K of $66.415 \mathrm{~mm} \cdot \mathrm{h}^{-1}$ ), the Salto Grande reservoir is located predominantly on Clayey/Very Clayey texture Haplic Nitosol (average SOL_K of $23.395 \mathrm{~mm} \cdot \mathrm{h}^{-1}$ ). For this reason, it was assumed that the losses by infiltration in this reservoir are smaller than those from the reservoir of the Caunal Dam, and the initial value was rounded off to $0.3 \mathrm{~mm} \cdot \mathrm{h}^{-1}$. As to the parameter EVRSV, due to the closeness of the 2 reservoirs, the atmospheric conditions are practically the same, thus the maximum value of this parameter was also adopted. Since the volume of the Salto Grande Dam is always kept at the maximum level, without any discharge from the emergency spillway, due to the fact that its inflow is regulated by the anthropic operation of the Caunal Dam (dam operator, personal communication in 2014), the initial volume of the Salto Grande Dam was not altered. On the other hand, the value of RES_RR, which was obtained by weighting areas based on the value of this parameter for the Caunal Dam, was also reduced by $15 \%$.

With this calibration all metrics had better values (Table 7). However, only the simulations of maximum flows were acceptable based on the values of NSE and $\mathrm{R}^{2}$, and also the mean volume discharged by the dam due to the value of MAE. Although the

Table 10. Manual Calibration of the RPW Sediment Yield.

\begin{tabular}{ccccc}
\hline PARAMETER & INITIAL VALUE & OPERATION & OPERATION VALUE & FINAL VALUE \\
\hline USLE_P & Several* & Multiplication & 0.50 & Several* \\
USLE_C & $0.20^{*}$ & Multiplication & 0.50 & $0.10^{*}$ \\
USLE_K & Several & Multiplication & 0.75 & Several \\
SOL_BD & Several & Multiplication & 0.75 & Several \\
ADJ_PKR & 1 & Multiplication & 0.50 & 0.50 \\
CH_BNK_D & 61.04 & Multiplication & 1.25 & 76.30 \\
CH_BED_D & 95.37 & Multiplication & 1.25 & 119.2125 \\
CH_BNK_BD & 1.19 & Multiplication & 0.75 & 0.8925 \\
CH_BED_BD & 1.49 & Multiplication & 0.75 & 1.1175 \\
CH_BNK_TC & 73.23 & Multiplication & 4 & 292.92 \\
CH_BED_TC & 19.44 & Multiplication & 4 & 77.76 \\
CH_BNK_KD & 0.0234 & Re-estimated & 0.0117 & 0.0117 \\
CH_BED_KD & 0.0454 & Re-estimated & 0.0227 & 0.0227 \\
\hline
\end{tabular}

*Only in AGRR and AGRL. 
overestimate presented in the PBIAS value was reduced by more than half in relation to the previous procedure, and the value of LogNSE became greater than zero, these two indices remained unsatisfactory. During the validation period, the values of the metrics improved in relation to the previous procedure, but only two were acceptable.

Due to the hydrological calibration, the underestimate of the sedimentological simulation of the reservoir increased, worsening its evaluation indices. Thus, the sediment balance calibration aimed at increasing the estimate of the solid discharges, diminishing the estimate of sediment deposition.

Since parameter RES_D 50 presented low sensitivity to calibration, its initial value was not altered. Only parameters RES_NSED and RES_SED were adjusted together, since the individual adjustments proved inefficient. In order to improve the value of the evaluation metrics, it was necessary to increase the initial value of these parameters by 32 times, considering that the smaller adjustments presented little sensitivity. This excessive increase is justified in the case of RES_NSED, by the great uncertainty in its initial value, in which the mean value of SSC was used, obtained by point samplings performed by Zanin, Bonuma and Franco (2017). Now, for parameter RES_SED, in which the same initial value of RES_NSED was used, this excessive increase is justified, because of the reduction of the initial volume of the reservoir performed in the calibration of the water balance. Thus, there is less dilution of the sediment in aqueous medium, increasing the concentration. For the Salto Grande Dam the same values of the sedimentological parameters of the Caunal Dam were adopted. Table 11 shows the summary of the water and sediment balance calibrations of the two dams.

With these adjustments it was possible to improve the values of the metrics during the calibration period, and four acceptable indices were obtained. The sedimentological simulation was only not satisfactory due to the value of LogNSE, which despite being positive is not acceptable. On the other hand, in the validation period, while the values of $\mathrm{R}^{2}$ and PBIAS improved, in the other metrics they became worse (Table 8).

The hydrological calibrations of the reservoirs impaired the flow routing toward downstream, increasing the underestimate in the RPW, and slightly impairing all indices. The metrics of satisfactory values in the previous procedure were maintained as such during the calibration period, while in the validation period
LogNSE and $\mathrm{R}^{2}$ were more affected, and the latter was no longer satisfactory. As to the production of sediments by the RPW, the calibration of the reservoirs minimally affected the evaluation indices, increasing the overestimation during the calibration period and reducing the underestimation during the validation period (Tables 7 and 8).

\section{Comparison of modeling procedures}

In this topic, the 3 modeling procedures performed in this study are compared. Due to the better evaluation indices during the calibration period, the wet year of 2011 and the dry year of 2012 were analyzed. Figure 5 shows that the worst simulation of the water balance in both years for the RPW was that of the $1^{\text {st }}$ procedure, as expected. This occurs both because of the underestimate of the total volume and the proportion of base and surface flows in the composition of the total flow, due to the inversion of the pattern observed, with the surface runoff being greater than the base flow. The $2^{\text {nd }}$ and $3^{\text {rd }}$ procedures, however, provided a better representation of the data observed. They have the same pattern of proportions of base and surface flows observed, despite maintaining the underestimate which is slightly larger in the $3^{\text {rd }}$ that in the $2^{\text {nd }}$ procedure. As to these flows, it is important to observe that while the base flow is underestimated in both years, the surface runoff is underestimated in the wet year and overestimated in the dry year. In general, it is found that the simulations of total flow for the dry year were better than in the wet year. On the other hand, the simulation of the wet year was better to represent the proportion of surface runoff and base flow in the composition of the total flow.

The main deficiency of this modeling lies in the representation of base flow. Underestimates of hydrological simulations using SWAT for dry years were also found by Brighenti, Bonuma and Chaffe (2016) and Lubitz, Pinheiro and Kaufmann (2013), but with overestimates for the wet years. On the other hand, Green and Van Griensven (2008) found overestimates of dry periods and underestimates of wet periods. According to Kavetski, Kuczera and Franks (2006), it can be inferred that the underestimates may be due to the input and evaluation data of the model. In the modeling of the RPW, these limitations would be a) spatial limitation of the rainfall data, or b) quality of the streamflow rating curve.

Table 11. Manual calibration of reservoirs hydrosedimentological balance.

\begin{tabular}{cccccc}
\hline DAM & PARAMETER & INITIAL VALUE & OPERATION & OPERATION VALUE & FINAL VALUE \\
\hline CAUNAL & RES_K & 0.25 & Multiplication & 4.40 & 1.1 \\
& EVRSV & 0.60 & Replacement & 1 & 1 \\
& RES_VOL & $3,599.72$ & Multiplication & 0.50 & $1,799.86$ \\
& RES_RR & 2.73 & Multiplication & 0.85 & 2.3205 \\
SALTO GRANDE & RES_NSED & 8.64 & Multiplication & 32 & 276.48 \\
& RES_SED & 8.64 & Multiplication & 32 & 276.48 \\
& RES_K & 0.25 & Replacement & 0.30 & 0.30 \\
& EVRSV & 0.60 & Replacement & 1 & 1 \\
& RES_RR & 4.12 & Multiplication & 0.85 & 3.502 \\
& RES_NSED & 8.64 & Multiplication & 32 & 276.48 \\
& RES_SED & 8.64 & Multiplication & 32 & 276.48 \\
\hline
\end{tabular}




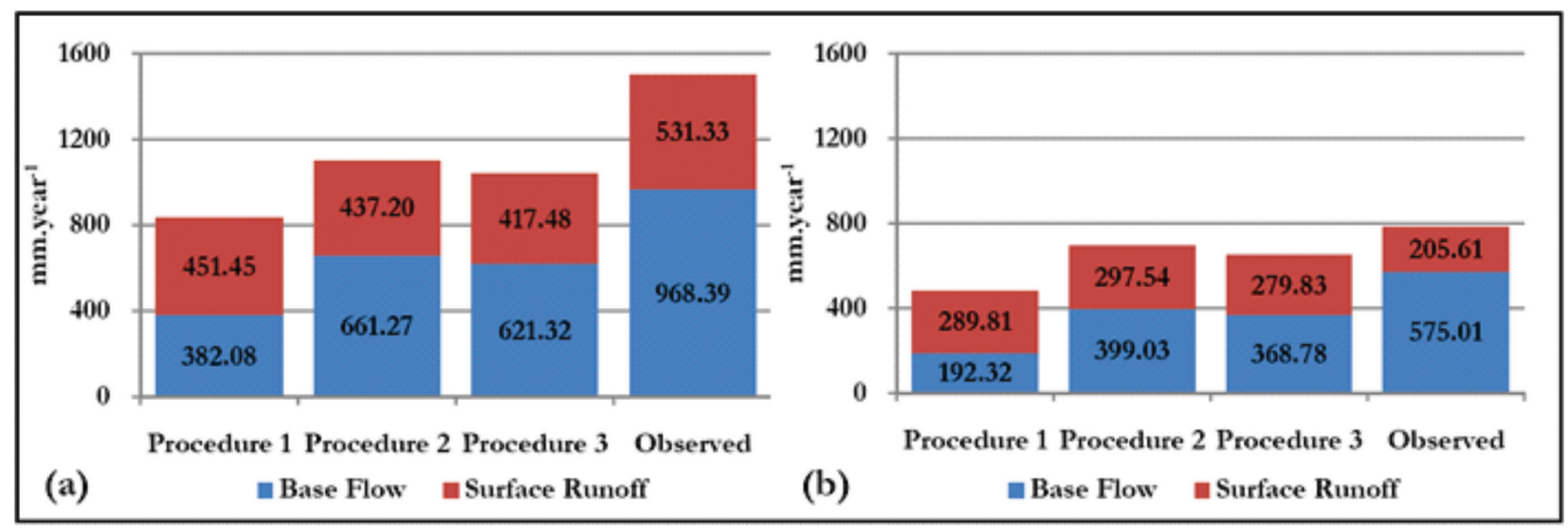

Figure 5. Simulated and observed water balances of the RPW. (a) Wet and (b) dry years.

However, according to Sikorska and Renard (2017), this limitation may be due to structural issues of the model. The surface runoff and base flow data used in Figure 5 were obtained by separating the fluvial flow. Thus, the deficiency in the representation of the base flow may be due to the use of the Muskingum method for flow routing in the channel.

At the same time as the Muskingum method simulated the shape of the RPW hydrograph, similar to the observed hydrograph, even without calibration, it also simulated streamflow with null (zero) values. When the Variable Storage method is used for flow routing (not shown) the simulated hydrograph presents the opposite behavior, since without calibration it is not able to represent the shape of the observed hydrograph, but it does not simulate flows equal to zero.

The great different between these two methods is that, while the Variable Storage method is based only on the continuity equation, the Muskingum method is based on the continuity equation associated with that of storage. In the latter, the volume stored along the channel combines wedge shaped storage (flood wave) with prism shaped storage (volume of the constant cross-section along the segment) (NEITSCH et al., 2011). Since it utilizes geometric forms to represent flow routing, the Muskingum method is sensitive to the channel dimensions. As this study chose to simulate the degradation of the river section, its dimensions are actualized throughout the simulation. With the elongation of the channel base in the river segments upstream, there is a reduction of the hydraulic radius in the trapezoidal section, increasing the action of channel roughness on the runoff volume. This makes the parameterization of the prism shaped storage reduce the water input to the downstream segments, generating null flows at the RPW mouth. This finding is based on the significant reduction of the flows equal to zero by correcting the channel width in the pre-simulations (not shown). However, these limitations still need further investigation.

As to the sediment yield for the wet and dry year (Figure 6), inverse behavior occurs as related to water production in the RPW. The simulation in the $1^{\text {st }}$ procedure is still the worst of all, but now overestimating the data observed. On the other hand the $2^{\text {nd }}$ and $3^{\text {rd }}$ procedures are closer to the data observed, but also with an overestimation, being slightly larger in the $3^{\text {rd }}$ than in the $2^{\text {nd }}$ procedure. In all procedures, sediment yield from the fluvial environment is higher to that from the landscape. This result corroborates that of Liu et al. (2015), who, on simulating the production of sediments with SWAT in a predominantly agricultural basin, found a proportion of $40 \%$ and $60 \%$ in the production from the landscape and river channel, respectively. Since the RPW is predominantly forested, it is acceptable that the production of sediments from the river environment represents 93\% (dry year) and $96 \%$ (wet year) of the total production of sediments, in the $2^{\text {nd }}$ and $3^{\text {rd }}$ procedures, despite the overestimate.

Additionally, there was a better simulation of sediment yield in the wet year than in the dry year. While in the former year the river production is greater than in the latter, the sediment production of the landscape is greater in the dry year than in the wet year. Since the water production is being underestimated and the sediment yield is being overestimated in all modeling procedures, the erodibility simulated in the channels is greater than what really happens. This may be due to the use of the Yang Sand and Gravel method for sediment routing in a fluvial environment. According to Jeong et al. (2011), its parameters have more influence on sediment yield than the erosion caused by surface runoff on the landscape.

In the nested basin referring to the Caunal Dam (Figure 7a) all the procedures overestimate the flow data observed. However, the $1^{\text {st }}$ procedure provided a better simulation of the liquid discharge from the dam than the second one, while the $3^{\text {rd }}$ procedure is the most representative of the reality of this dam, as was to be expected. As to the wet and dry year, both simulations overestimate the data observed, practically to the same magnitude. The representativity of solid discharge from this dam (Figure 7b) gradually improved from the first to the third procedure, where the simulated totals were very close to reality, with the wet year being underestimated and the dry year overestimated.

This inversely proportional relation of sediment yield between the wet year and the dry year at Caunal Dam is due to the inversely proportional relation between volume and concentration of physicochemical elements present in the reservoir. In the wet year, despite more sediment input, the greater availability of water for the reservoir provides more dilution of concentration in an aqueous medium. In the dry year, however, the less water 


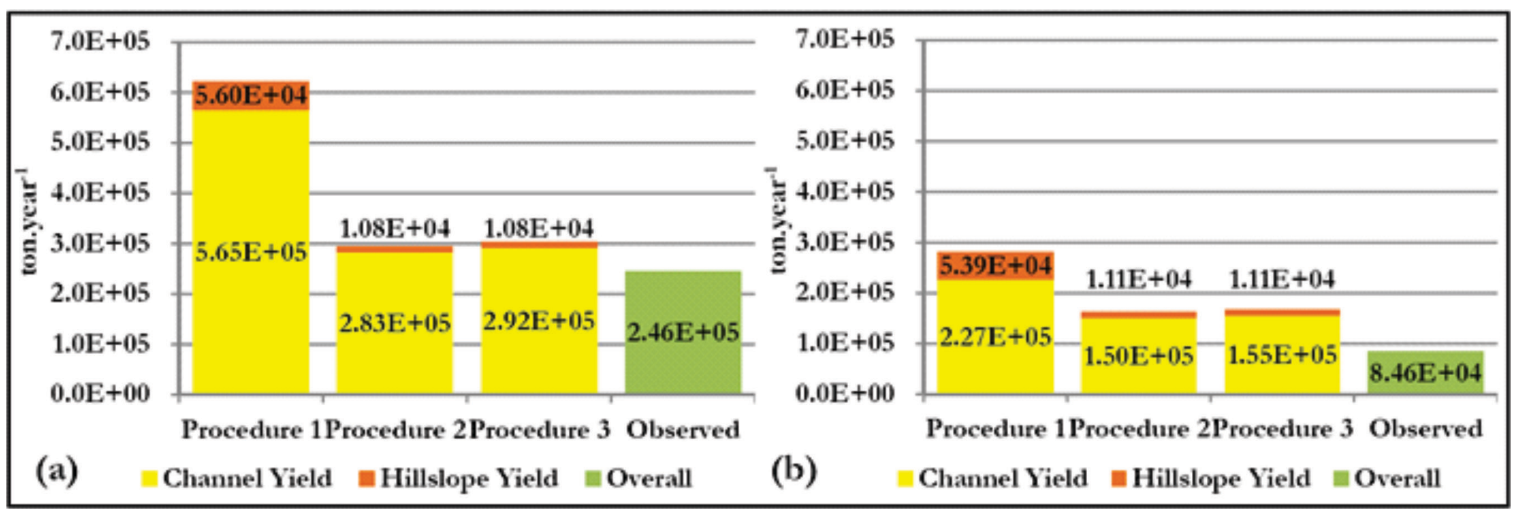

Figure 6. Simulated and observed sediment yield of the RPW. (a) Wet and (b) dry years.

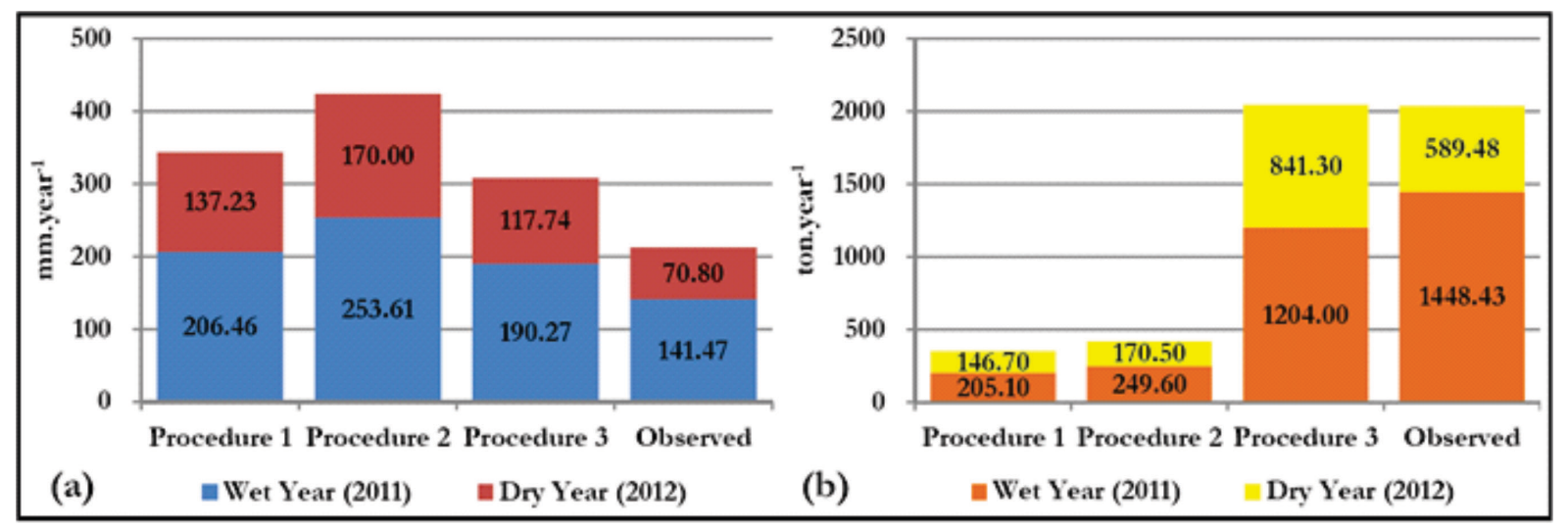

Figure 7. Caunal Dam. (a) Liquid and (b) solid discharges.

available, although it results in a smaller influent input of sediments, increases the concentration of the different physicochemical elements in the reservoir (LEMES, 2001; SOARES, 2011). Besides, Cabral et al. (2009) found that in a large elongated reservoir, similar to the Caunal Dam reservoir, the concentrations are more homogeneous in the wet period and more heterogeneous in the dry period with increased SSC.

\section{Temporal evaluation of the best calibration procedure}

Considering only the values of the evaluation metrics, the 2 nd procedure was the most efficient for the RPW. However, Bai, Shen and Yan (2017) consider the multi-site calibration more efficient than simple calibration, due to the correct representation of the parameter heterogeneity within the basin studied, and not due to the slight gain that they achieved in the evaluation indices utilized. Thus, although in the $3^{\text {rd }}$ procedure there was a slight reduction in the values of the metrics for the RPW compared to the previous procedure, both procedures for streamflow and sediments were satisfactory during the calibration period and non-satisfactory during the validation period. At the same time, the values of the metrics for a nested basin, as well as the number of acceptable indices are more representative in the $3^{\text {rd }}$ procedure. Thus, the last calibration procedure was the most effective to represent the physical processes of the watershed.

Analyzing Figure 8, it is observed that in the RPW the simulated hydrograph has more "noise" than the observed hydrograph. This may be due to the fact that the simulated surface runoff is being generated faster than really occurs in the basin. Despite this, it is found that in the calibration period the simulation kept up well with the behavior of the observed data, except for 2 events of fluviometric minimums that were strongly underestimated in 2012. For the validation period, the first half of 2013 and the end of 2014 were strongly underestimated. However, between these 2 periods, the simulated data provided a good representation of the behavior of the observed data.

Both in the calibration and in the validation period, the model underestimated the maximum fluviometric events. This underestimate is not necessarily due to the estimation of the parameter calibration values, it may be due to structural issues of the model (SIKORSKA; RENARD, 2017), since USEPA (2002) and Zeiger and Hubbart (2016) identified limitations of SWAT in representing extreme events. It may also be related to the limitations in the evaluation data of modeling (KAVETSKI; 


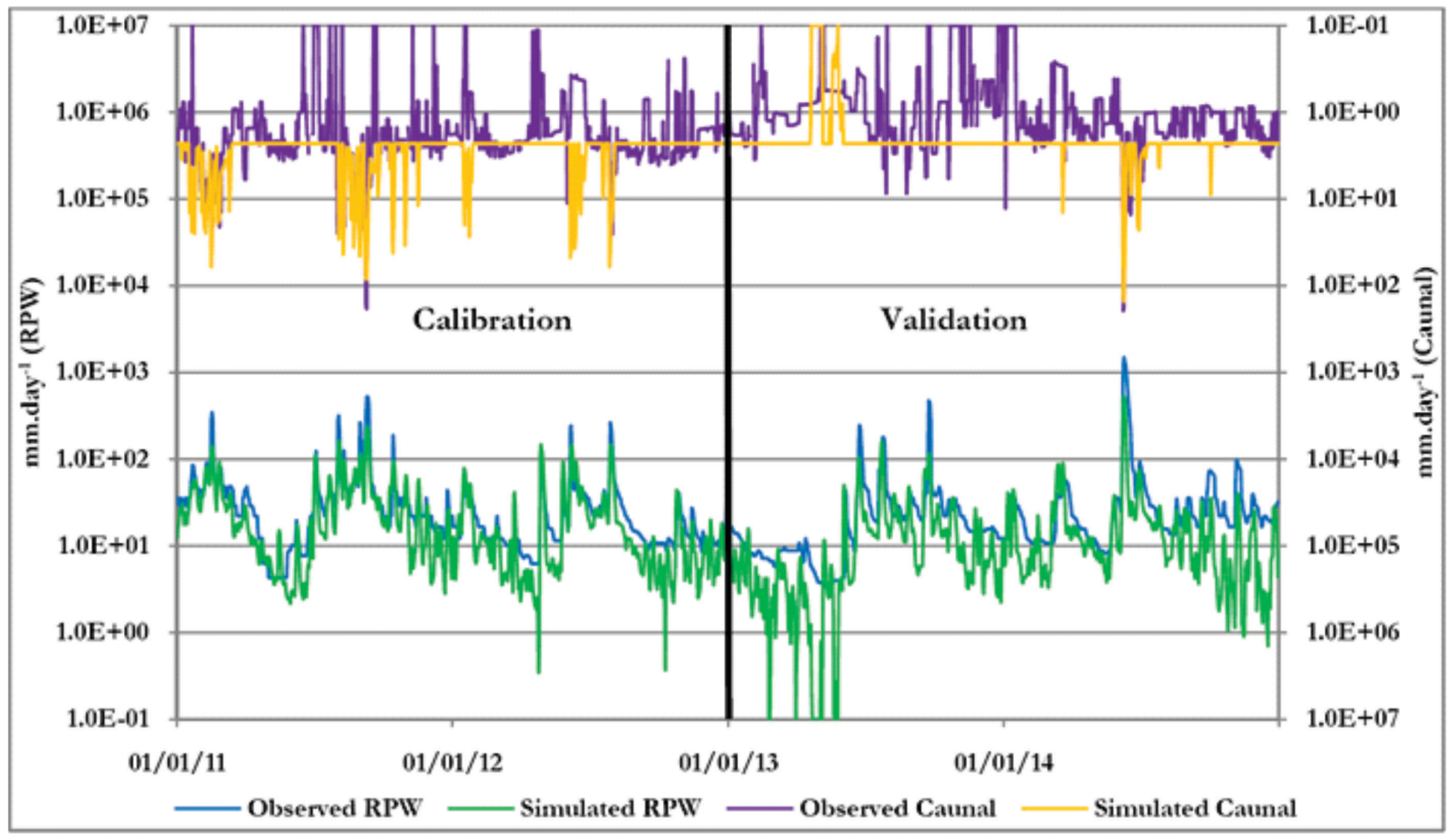

Figure 8. Hydrographs of the RPW (Lower) and Caunal Dam (Upper).

KUCZERA; FRANKS, 2006), since the records of levels of the largest extreme event that occurred in the study area were corrected using the regression model, which overestimates the data observed on average by $29 \%$. Additionally, the main extreme events of the series of streamflow are beyond the values measured in river mouth, that were used to build the rating curve. It should be pointed out that seasonal calibration schemes (MULETA, 2012; ZHANG et al., 2015a) can reduce this limitation.

In the Caunal Dam hydrograph, shown in the upper part of Figure 8 , it is found that in most of the calibration and validation periods, the liquid discharge was simulated by the value utilized for RES_RR. As to the minimal discharges from the dam, the only events represented by the model were in the first half of 2013, a period in which the reservoir was well below its normal level (below the $1^{\text {st }}$ quartile of the levels recorded from 2010 to 2014). The other minimum discharges from the dam, that were not simulated by the model, are due to the anthropic regulation of the Caunal Dam, in order to maintain the best hydraulic use for the reservoir of the Salto Grande hydropower plant (downstream).

As to the maximum hydrological events, resulting from the discharges of the emergency spillway and/or the maximum opening of the main spillway gate of the Caunal Dam, the model performed a good simulation of the calibration period. However, for the validation period, it only represented satisfactorily the extreme event that occurred in mid 2014. Besides, it should be underscored that in the 2 main extreme events of maximum flow that occurred in 2011 and 2014, the model underestimated the peaks. The dam hydrograph also shows that while minimum or null flows were observed, the model simulated large discharges, as for instance in the beginning of 2012 and in the events of the first and third quarter of 2014, which are due to the anthropic operation of the Caunal Dam mentioned previously. In other words, during rainfall events, the Salto Grande Dam is supplied by its contribution area, except for the area that contributes to the Caunal Dam, and therefore the gate of the Caunal Dam is closed by the operator, increasing its volume. It should be mentioned that none of the water release methods from SWAT reservoirs takes into account this specificity of operating reservoirs as a cascade. In is way, the difficulty of calibrating lies in structural limitations of the model, and not in the estimates of the parameters (SIKORSKA; RENARD, 2017).

As to the solid discharges, Figure 9 shows that the data modeled kept up reasonably with the behavior of the RPW data observed, in both simulation periods. There was a predominance of the overestimates of the mean values and underestimates of the peaks, and for the minimum values the only marked underestimates occurred in the first half of 2013, as a consequence of the underestimation of the liquid discharge discussed previously.

In the Caunal Dam (upper part of Figure 9), the constant values of liquid discharge that predominated in both periods were replaced by values with small temporal variations, which in the calibration period accompanied the mean values of the solid discharges observed. As to the minimum and maximum values for the calibration period, the minimum events were not represented, on the contrary of the maximum events, despite the underestimation of the main peak. A few events of minimum discharges from the dam were simulated as maximum events, due to the anthropic regulation of the dam during rainfall periods. However, during the validation period, the simulated data do not represent the behavior of the observed data from the dam. 


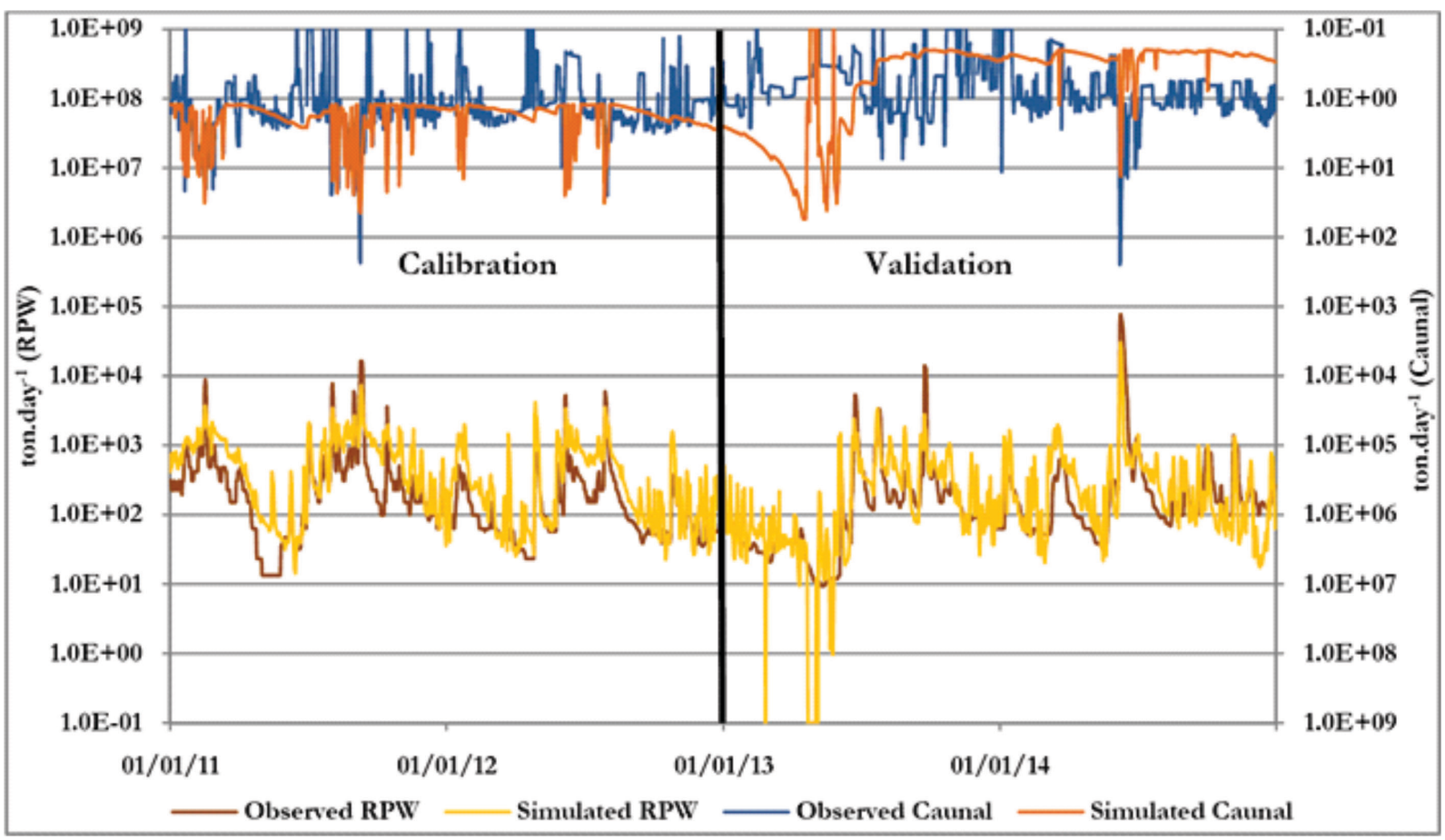

Figure 9. Solid discharges of the RPW (Lower) and Caunal Dam (Upper).

This is due mainly to the reduction in the reservoir volume at the beginning of 2013, resulting in the excessive increase of the SSC, generating large solid discharges. Consequently, the discharges from mid 2013 onward were deregulated, leading to underestimate the data observed with the best representation of this period occurring in the extreme event of June 2014, despite the strong underestimation of the sedimentological peak.

This limitation for the validation period of the solid discharge from the dam, above all the extremely dry period in the beginning of 2013, can be rather due to structural problems of the model than to parameter estimates (SIKORSKA; RENARD, 2017). Bryant et al. (2006) found that SWAT had limitations in simulating extremely dry and wet periods. It is also underscored that only one value was inserted for RES_NSED and RES_SED in the entire reservoir. When analyzing SSC in an elongated reservoir (like the reservoir of the Caunal Dam) Cabral et al. (2009) found differences along the reservoir, with the highest concentrations in the intermediate and upper part of the reservoir, and the smaller ones occurring in the lower part, close to the dam.

\section{CONCLUSIONS}

The present study evaluated the simple and multi-site calibration techniques in nested $6^{\text {th }}(\mathrm{RPW})$ and $5^{\text {th }}$ (Caunal Dam) order river basins with reservoirs. Although no analysis was performed of the uncertainties contained in the outputs from the model, according to the recommendation of Todini (2007), the results obtained are valid to respond to the objective proposed in this study. Thus, the following conclusions were formulated: (a) For a $6^{\text {th }}$ order river basin it was found that with simple calibration (evaluated with data measured at the mouth of the main basin), and considering only the parameters of the intrinsic processes of the watershed and management of rural areas, the evaluation indices as well as the annual totals were better than performing the multi-site calibration. However the simple calibration was not validated in the $5^{\text {th }}$ order river basin which, in turn, on the contrary of the higher order basin, was overestimating the liquid discharges and underestimating the solid discharges showing that spatially the hydrosedimentological processes are being erroneously simulated;

(b) Calibrating the reservoir that corresponds to the mouth of the $5^{\text {th }}$ order river basin, it was possible to improve the hydrosedimentological simulations during the calibration period. However, in both periods, the simulations were not satisfactory. As to the hydrological simulation, the limitation of the methods of water release from the reservoirs in this version of SWAT is emphasized. They do not take into account the cascade operation, where the discharges from the upstream reservoir are regulated by the volume of the downstream reservoir. On the other hand, the limitation of the solid discharges that carry in themselves the limitation of the hydrological simulation can be explained by two reasons. The first may be due to the evaluation data observed, since the data used to construct the flow-solid discharge rating curve were sampled by Zanin, Bonuma and Franco (2017) during the wet year of 2014, without taking into account the levels of the aforementioned reservoir during dry periods. The second 
reason may be the structural limitation of the model, since the reservoir module parameters of SWAT are spatially concentrated, while the sediment balance in large reservoirs is not homogeneous throughout their length;

(c) With the multi-site calibration of the nested basins, the values of the metrics used to evaluate the $6^{\text {th }}$ order river basin, as well as their annual totals, suffered a slight loss in relation to the simple calibration, and remained satisfactory only during the calibration period. The reservoir that represents the mouth of the nested basin, however, had significant gains in its evaluation indices, although they were not satisfactory. Thus, despite the slight reduction of the indices of the $6^{\text {th }}$ order river basin, the multi-site calibration is more representative of the hydrosedimentological heterogeneity of the study area as a whole;

d) The opposite behavior was found in the estimates of the model between the nested basins. In both the evaluation periods, the $6^{\text {th }}$ order river basin underestimates the streamflow, while the $5^{\text {th }}$ order river basin overestimates the liquid discharges. At the same time, during the calibration period, while the $6^{\text {th }}$ order river basin overestimates sediment yield, the $5^{\text {th }}$ order river basin underestimates it. This may be for two reason, referring to the limitation of the input data and the evaluation of the model. The former refers to the limited spatial representativity in some of the 3 point sources of rainfall. At the same time as each station is located in one of the 3 main sub-basins of the RPW, the CVG and Corredeira stations are in the intermediate portions of their sub-basins, while the Moema station is in the boundary of the RPW. The second reason refers to the limitation of the series of streamflow data observed, since besides filling out the gaps in the level records of the largest extreme event of the data series, the main events of fluviometric maximums are beyond the limit of extrapolation of the streamflow rating curve for the $6^{\text {th }}$ order river basin, and also for the total solid discharge rating curve of this basin;

e) The inverse relation mentioned previously, made the calibration between the watershed and internal reservoirs correct opposite tendencies in the model estimates. This made the improvement in the simulation of the watershed impair that of the nested basin and vice-versa. This is due to the complexity of the interaction between artificial processes (reservoirs) and intrinsic processes of the watershed in solving the model. However, the combined calibration among these processes in different nested basins improves the spatial representativity of the processes within the watershed. Thus, the multi-site calibration makes it easier to identify the sub-sectors and/or processes responsible for the limitations in hydrosedimentological simulation.

Thus, it is recommended to perform the multi-site calibration of SWAT in fluvial systems with the presence of reservoirs, adjusting the parameters that represent the intrinsic and artificial processes in the watershed. For the new formulations of this model, it is recommended that the reservoir module be modified, in order to consider the sedimentological heterogeneity of large artificial lakes. It is also recommended that a new water discharge method be considered, taking into account the cascade operation between 2 or more reservoirs, where the upstream dam must regulate the volume of the downstream reservoir.

\section{ACKNOWLEDGEMENTS}

To the CNPq for the study scholarship. To the FINEP for the funding of this research. To the editor and reviewers of RBRH for their contributions in this article.

\section{REFERENCES}

ALLEN, R. G. A Pennam for all seasons. Journal of Irrigation and Drainage Engineering, v. 112, n. 4, p. 348-368, 1986. http://dx.doi. org/10.1061/(ASCE)0733-9437(1986)112:4(348).

ALLEN, R. G.; JENSEN, M. E.; WRIGHT, J. L.; BURMAN, R. D. Operational estimates of evapotranspiration. Agronomy Journal, v. 81, n. 4, p. 650, 1989. http://dx.doi.org/10.2134/agronj1989. 00021962008100040019x.

ALVARES, C. A.; STAPE, J. L.; SENTELHAS, P. C.; MORAES GONÇALVES, J. L.; SPAROVEK, G. Köppen's climate classification map for Brazil. Meteorologische Zeitschrif, v. 22, n. 6, p. 711-728, 2013. http://dx.doi.org/10.1127/0941-2948/2013/0507.

ARAGÃO, R.; CRUZ, M. A. S.; AMORIM, J. R. A.; MENDONÇA, L. C.; FIGUEIREDO, E. E.; SRINIVASAN, V. S. Análise de sensibilidade dos parâmetros do modelo SWAT e simulação dos processos hidrossedimentológicos em uma bacia no agreste nordestino. Revista Brasileira de Ciência do Solo, v. 37, n. 4, p. 1091 1102, 2013. http://dx.doi.org/10.1590/S0100-06832013000400026.

ARNOLD, J. G.; WILLIAMS, J. R. Validation of SWRRB: simulator for water resources in rural basins. Journal of Water Resources Planning and Management, v. 113, n. 2, p. 243-256, 1987. http://dx.doi.org/10.1061/(ASCE)0733-9496(1987)113:2(243).

ARNOLD, J. G.; ALLEN, P. M.; MUTTIAH, R.; BERNHARDT, G. Automated base flow separation and recession analysis techniques. Ground Water, v. 33, n. 6, p. 1010-1018, 1995a. http:// dx.doi.org/10.1111/j.1745-6584.1995.tb00046.x.

ARNOLD, J. G.; WILLIAMS, J. R.; MAIDMENT, D. R. Continuoustime water and sediment-routing model for large basins. Journal of Hydraulic Engineering, v. 121, n. 2, p. 171-183, 1995b. http:/ /dx.doi. org/10.1061/(ASCE)0733-9429(1995)121:2(171).

ARNOLD, J. G.; SRINIVASAN, R.; MUTTIAH, R. S.; WILLIAMS, J. R. Large area hydrologic modeling and assessment: part 1. Model development. Journal of the American Water Resources Association, v. 34, n. 1, p. 73-89, 1998. http://dx.doi.org/10.1111/j.1752-1688.1998. tb05961.x. 
ARNOLD, J. G.; MORIASI, D. N.; GASSMAN, P. W.; ABBASPOUR, K. C.; WHITE, M. J.; SRINIVASAN, R.; SANTHI, C.; HARMEL, R. D.; VAN GRIENSVEN, A.; VAN LIEW, M. W.; KANNAN, N.; JHA, M. K. SWAT: model use, calibration, and validation. Transactions of the ASABE, v. 55, n. 4, p. 1491-1508, 2012a. http:/ / dx.doi.org/10.13031/2013.42256.

ARNOLD, J. G.; KINIRY, J. R.; SRINIVASAN, R.; WILLIAMS, J. R.; HANEY, E. B.; NEITSCH, S. L. Soil and water assessment tool input/ output documentation version 2012. Texas: Texas Water Resources Institute, 2012b. vol. TRF-439.

BAI, J.; SHEN, Z.; YAN, T. A comparison of single- and multisite calibration and validation: a case study of SWAT in the Miyun Reservoir watershed, China. Frontiers of Earth Science, v. 11, n. 3, p. 592-600, 2017. http://dx.doi.org/10.1007/s11707-017-0656-x.

BARBETTA, P. A. Estatística aplicada às Ciências Sociais. 7. ed. Florianópolis: UFSC, 2011.

BEGOU, J. C.; JOMAA, S.; BENABDALLAH, S.; BAZIE, P.; AFOUDA, A.; RODE, M. Multi-site validation of the SWAT model on the Bani Catchment: model performance and predictive uncertainty. Water. Water (Basel), v. 8, n. 5, p. 178, 2016. http:// dx.doi.org/10.3390/w8050178.

BEKELE, E. G.; NICKLOW, J. W. Multi-objective automatic calibration of SWAT using NSGA-II. Journal of Hydrology, v. 341, n. 3-4, p. 165-176, 2007. http://dx.doi.org/10.1016/j. jhydrol.2007.05.014.

BLOSCHL, G.; SIVAPALAN, M. Scale issues in hydrological modelling: a review. Hydrological Processes, v. 9, n. 3-4, p. 251-290, 1995. http://dx.doi.org/10.1002/hyp.3360090305.

BRAKENSIEK, D. L. Kinematic flood routing. Transactions of the ASAE. American Society of Agricultural Engineers, v. 10, n. 3, p. 340-343, 1967. http://dx.doi.org/10.13031/2013.39668.

BRESSIANI, D. A.; GASSMAN, P. W.; FERNANDES, J. G.; GARBOSSA, L. H. P.; SRINIVASAN, R.; BONUMA, N. B.; MEDIONDO, E. D. Review of Soil and Water Assessment Tool (SWAT) applications in Brazil: challenges and prospects. International Journal of Agricultural and Biological Engineering, v. 8, n. 3, p. 9-35, 2015.

BRIGHENTI, T. M.; BONUMA, N. B.; CHAFFE, P. L. B. Calibração hierárquica do modelo SWAT em uma bacia hidrográfica Catarinense. Revista Brasileira de Recursos Hídricos, v. 21, n. 1, p. 53-64, 2016. http://dx.doi.org/10.21168/rbrh.v21n1.p53-64.

BROUZIYNE, Y.; ABOUABDILLAH, A.; BOUABID, R.; BENAABIDATE, L.; OUESLATI, O. SWAT manual calibration and parameters sensitivity analysis in a semi-arid watershed in North-western Morocco. Arabian Journal of Geosciences, v. 10, n. 19, p. 427, 2017. http://dx.doi.org/10.1007/s12517-017-3220-9.
BROWN, L. C.; BARNWELL JUNIOR, T. O. The enhanced water quality models QUAL2E and QUAL2E-UNCAS: documentation and user manual. Athens: USEPA, 1987. EPA document EPA/600/3-87/007.

BRYANT, R. B.; GBUREK, W. J.; VEITH, T. L.; HIVELY, W. D. Perspectives on the potential for hydropedology to improve watershed modeling of phosphorous loss. Geoderma, v. 131, n. 3-4, p. 299-307, 2006. http://dx.doi.org/10.1016/j.geoderma.2005.03.011.

CABRAL, P.; BATISTA, J.; FERNANDES, L. A.; BECEGATO, V. A.; ALVES, S. S. Concentração de sedimentos em suspensão: reservatório de Cachoeira Dourada - GO/MG, Brasil. Revista de Geografia da UFC, v. 8, n. 16, p. 233-253, 2009.

CAO, W.; BOWDEN, W. B.; DAVIE, T.; FENEMOR, A. Multivariable and multi-site calibration and validation of SWAT in a large mountainous catchment with high spatial variability. Hydrological Processes, v. 20, n. 5, p. 1057-1073, 2006. http://dx.doi. org/10.1002/hyp.5933.

CARVALHO, N. O.; ALVES, C. F. C.; OLIVEIRA, A. M. S.; BURATO, R. B.; PERRELLA, M. C. V.; CELERI, A.; TANAKA, R.; FERREIRA, A. S. Estudo Hidrossedimentológico do Reservatório de Porto Primavera, Rio Paraná. In: ENCONTRO NACIONAL DE ENGENHARIA DE SEDIMENTOS, 6., 2004, Vitória, ES. Anais... Porto Alegre: ABRH, 2004.

CARVALHO, N. O.; FILIZOLA, N. P.; SANTOS, P. M. C.; LIMA, J. E. F. W. Guia de práticas sedimentométricas. Brasília: Agência Nacional de Energia Elétrica, Superintendência de Estudos e Informações Hidrológicas, 2000.

CHAFFE, P. L. B. Monitoramento e modelagem do processo Chuva-vazão de uma pequena bacia florestal com ênfase em interceptação. 2009. $100 \mathrm{f}$. Dissertação (Mestrado em Engenharia Ambiental) - Programa de Pós-graduação em Engenharia Ambiental, Universidade Federal de Santa Catarina, Florianópolis, 2009.

CHIANG, L. C.; YUAN, Y.; MEHAFFEY, M.; JACKSON, M.; CHAUBEY, I. Assessing SWAT's performance in the Kaskaskia River watershed as influenced by the number of calibration stations used. Hydrological Processes, v. 28, n. 3, p. 676-687, 2014. http:// dx.doi.org/10.1002/hyp.9589.

CHO, J.; BOSCH, D.; VELLIDIS, G.; LOWRANCE, R.; STRICKLAND, T. Multi-site evaluation of hydrology component of SWAT in the coastal plain of southwest Georgia. Hydrological Processes, v. 27, n. 12, p. 1691-1700, 2013. http://dx.doi.org/10.1002/ hyp. 9341.

CHOW, V. T. Open-channel bydraulics. New York: McGraw-Hill, 1959.

COLBY, B. R. Relationship of unmeasured sediment discharge to mean velocity. Transactions - American Geophysical Union, v. 38, n. 5, p. 708-719, 1957. http://dx.doi.org/10.1029/TR038i005p00708. 
CONGALTON, R. G.; GREEN, K. Assessing the accuracy of remotely sensed data: principles and practices. New York: Lewis Publishers, 1999.

CPRM - SERVIÇO GEOLÓGICO DO BRASIL. GEOBANK. Brasília, 2007. Available from: <http://geobank.sa.cprm.gov.br/>. Access on: 21 feb. 2013.

CREECH, C. T.; SIQUEIRA, R. B.; SELEGEAN, J. P.; MILLER, C. Anthropogenic impacts to the sediment budget of São Francisco River using SWAT. International Journal of Agricultural and Biological Engineering, v. 8, n. 3, p. 140-157, 2015.

DAGGUPATI, P.; YEN, H.; WHITE, M. J.; SRINIVASAN, R.; ARNOLD, J. G.; KEITZER, C. S.; SOWA, S. P. Impact of model development, calibration and validation decisions on hydrological simulations in West Lake Erie Basin. Hydrological Processes, v. 29, n. 26, p. 5307-5320, 2015. http://dx.doi.org/10.1002/hyp.10536.

DOOGE, J. C. I. The linear theory of bydrologic systems. Washington: U.S. Government Printing Office, 1973. 327 p. (Techical Bulletin, 1468).

EDUARDO, E. N.; MELLO, C. R.; VIOLA, M. R.; OWENS, P. R.; CURI, N. Hydrological simulation as subside for management of surface water resources at the Mortes River Basin. Ciência e Agrotecnologia, v. 40, n. 4, p. 390-404, 2016. http://dx.doi. org/10.1590/1413-70542016404009516.

EMAM, A. R.; KAPPAS, M.; NGUYEN, L. H. K.; RENCHIN, T. Hydrological modeling in an ungauged basin of central Vietnam using SWAT model. Hydrology and Earth System Sciences, v. 44, p. 1-33, 2016.

EPAGRI/IBGE - EMPRESA DE PESQUISA AGROPECUÁRIA E EXTENSÃO RURAL DE SANTA CATARINA/INSTITUTO BRASILEIRO DE GEOGRAFIA E ESTATÍSTICA. Mapoteca topográfica digital de Santa Catarina. Florianópolis, 2004. Available from: <http://ciram.epagri.sc.gov.br/mapoteca>. Access on: 21 feb. 2013.

FAN, F. M.; COLLISCHONN, W.; SORRIBAS, M. V.; PONTES, P. R. M. Sobre o início da rede de drenagem definida a partir dos modelos digitais de elevação. Revista Brasileira de Recursos Hídricos, v. 18, n. 3, p. 241-257, 2013. http://dx.doi.org/10.21168/rbrh. v18n3.p241-257.

FASOLO, P. J.; POTTTER, R. O.; CARVALHO, A. P.; FLORES, C. A.; BOGNOLA, I.; RAUEN, M. J.; CARDOSO, A.; HOCHMULLER, D. P.; RIBAS, G. C.; RACHWAL, M. F.; GUIMARÃES, S.; SANTOS, H. G.; AGLIO, M. L. D.; CHAFFIN, C. E.; SOUZA, J. S. Levantamento de reconbecimento de solos do Estado de Santa Catarina: escala 1:250.000. Brasília: EMBRAPA, 2004. Formato Shapefile. Available from: <http://mapoteca.cnps.embrapa.br/>. Access on: 21 feb. 2013

FERNANDES, C. V. S.; FERMIANO, G. A.; FILL, H. D. O. A.; SANTOS, I.; CHELLA, M. R. Avaliação do transporte de sedimentos no Rio Barigui. Revista Brasileira de Recursos Hídricos, v. 10, n. 3, p. 105111, 2005. http://dx.doi.org/10.21168/rbrh.v10n3.p105-111.

GARIZI, A. Z.; TALEBI, A. Identification of critical sediment source areas across the Gharesou watershed, Northeastern Iran, using hydrological modeling. Environmental Resources Research, v. 4, n. 1, p. 1-25, 2016.

GASSMAN, P. W.; REYES, M. R.; GREEN, C. H.; ARNOLD, J. G. The Soil and Water Assessment Tool: historical development, applications, and future research directions. American Society of Agricultural and Biological Engineers, v. 50, n. 4, p. 1211-1250, 2007.

GENOVEZ, A. M.; LOMBARDI NETO, F; SARTORI, A. Classificação hidrológica de solos brasileiros para a estimativa da chuva excedente com o método do serviço de conservação do solo dos Estados Unidos. Parte 1: classificação. Revista Brasileira de Recursos Hídricos, v. 10, n. 4, p. 5-18, 2005. http://dx.doi. org/10.21168/rbrh.v10n4.p5-18.

GIGLIO, J. N. Interceptação da chuva em pequena bacia experimental coberta por Floresta Ombrófila Mista. 2013. 194 f. Dissertação (Mestrado em Engenharia Ambiental) - Programa de Pós-graduação em Engenharia Ambiental, Universidade Federal de Santa Catarina, Florianópolis, 2013.

GREEN, C. H.; TOMER, M. D.; DI LUZIO, M.; ARNOLD, J. G. Hydrologic evaluation of the Soil and Water Assessment Tool for a large tile-drained watershed in Iowa. American Society of Agricultural and Biological Engineers, v. 49, n. 2, p. 413-422, 2006.

GREEN, C. H.; VAN GRIENSVEN, A. Autocalibration in hydrologic modeling: Using SWAT2005 in small-scale watersheds. Environmental Modelling \& Software, v. 23, n. 4, p. 422-434, 2008. http://dx.doi.org/10.1016/j.envsoft.2007.06.002.

GUIMARÃES, C. F. Simulação hidrológica e hidrossedimentológica em uma bacia com reservatórios com o modelo Soil and Water Assessment Tool (SWAT). Dissertação (Mestrado em Engenharia Ambiental) Programa de Pós-graduação em Engenharia Ambiental, Universidade Federal do Espírito Santo, Vitória, 2016.

HUDSON-EDWARDS, K. Fluvial environments. In: PERRY, C; TAYLOR, K. (Ed.). Environmental sedimentology. Oxford: Blackwell Publishing, 2007.

HUTCHINSON, M. F. Calculation of hydrologically sound digital elevation models. In: INTERNATIONAL SYMPOSIUM ON SPATIAL DATA HANDLING, 3., 1988, Sydney. Proceedings... Sydney: International Geographical Union, 1988.

HUTCHINSON, M. F. A new procedure for gridding elevation and stream line data with automatic removal of spurious pits. Journal of Hydrology, v. 106, n. 3-4, p. 211-232, 1989. http://dx.doi. org/10.1016/0022-1694(89)90073-5. 
JACOMINE, P. K. T. A nova classificação brasileira de solos. Anais da Academia Pernambucana de Ciência Agronômica, v. 5-6, p. 161-179, 2009.

JEONG, J.; KANNAN, N.; ARNOLD, J. G.; GLICK, R.; GOSSELINK, L.; SRINIVASAN, R.; HARMEL, R. D. Development of sub-daily erosion and sediment transport algorithms for SWAT. Transactions of the ASABE, v. 54, n. 5, p. 1685-1691, 2011. http:/ / dx.doi.org/10.13031/2013.39841.

JULIAN, P. J.; TORRES, R. Hydraulic erosion of cohesive riverbanks. Geomorphology, v. 76, n. 1-2, p. 193-206, 2006. http:// dx.doi.org/10.1016/j.geomorph.2005.11.003.

KAVETSKI, D.; KUCZERA, G.; FRANKS, S. W. Bayesian analysis of input uncertainty in hydrological modeling: 1. theory. Water Resources Research, v. 42, n. 3, p. W03407, 2006.

KIM, H.; PARAJULI, P. B. Impacts of reservoir outflow estimation methods in SWAT model calibration. Transactions of the ASABE, v. 57, n. 4, p. 1020-1042, 2014.

KLEMES, V. Conceptualisation and scale in hydrology. Journal of Hydrology, v. 65, n. 1-3, p. 1-23, 1983. http:/ /dx.doi.org/10.1016/00221694(83)90208-1.

KLEMES, V. Operational testing of hydrological simulation models. Hydrological Sciences Journal, v. 31, n. 1, p. 13-24, 1986. http://dx.doi.org/10.1080/02626668609491024.

LELIS, T. A.; CALIJURI, M. L.; SANTIAGO, A. F.; LIMA, D. C.; ROCHA, E. O. Análise de Sensibilidade e Calibração do Modelo SWAT aplicado em bacia hidrográfica da região sudeste do Brasil. Revista Brasileira de Ciência do Solo, v. 36, n. 2, p. 623-634, 2012. http://dx.doi.org/10.1590/S0100-06832012000200031.

LEMES, M. J. L. Avaliação de metais e elementos traço em águas e sedimentos das bacias hidrográficas dos rios Mogi - Guaçu e Pardo. 2001. 215 f. Dissertação (Mestrado em Ciências) - Instituto de Pesquisas Energéticas e Nucleares, Universidade de São Paulo, 2001.

LENHART, T.; ECKHARDT, K.; FOHRER, N.; FREDE, H.-G. Comparison of two different approaches of sensitivity analysis. Physics and Chemistry of the Earth, v. 27, n. 9-10, p. 645-654, 2002. http://dx.doi.org/10.1016/S1474-7065(02)00049-9.

LINO, J. F. L.; CORSEUIL, C. W.; KOBIYAMA, M.; MALUTTA, S.; UDA, P. K.; BORTOLOTTO, N. L.; SANTOS, I. Análise da vazão da bacia hidrográfica do Rio Preto com o modelo SWAT. In: SIMPÓSIO BRASILEIRO DE RECURSOS HÍDRICOS, 18., 2009, Campo Grande. Anais... Porto Alegre: ABRH, 2009.

LIU, Y.; YANG, W.; YU, Z.; LUNG, I.; GHARABAGHI, B. Estimating sediment yield from upland and channel erosion at a watershed scale using SWAT. Water Resources Management, v. 29, n. 5, p. 1399-1412, 2015. http://dx.doi.org/10.1007/s11269-014-0729-5.
LOPES, G. R.; TÁVORA, B. E.; SANTOS, R. M.; KOIDE, S. Reflexões sobre a elaboração e a aplicação de curva-chave de sedimentos em pequenas bacias. In: LIMA, J. E. F. W.; LOPES, W. T. A. (Ed.). Engenharia de sedimentos: na busca de soluções para problemas de erosão e assoreamento. Brasilia: ABRH, 2011.

LUBITZ, E.; PINHEIRO, A.; KAUFMANN, V. Simulação do transporte de sedimentos, nitrogênio e fósforo na Bacia do Ribeirão Concórdia, SC. Revista Brasileira de Recursos Hídricos, v. 18, n. 2, p. 39-54, 2013. http://dx.doi.org/10.21168/rbrh.v18n2.p39-54.

MALUTTA, S. Estudo hidrossedimentológico da bacia hidrográfica do Rio Negrinho - SC com o modelo SWAT. 2012. 126 f. Dissertação (Mestrado em Engenharia Ambiental) - Universidade Federal de Santa Catarina, Florianópolis, 2012.

MARCINKOWSKI, P.; PINIEWSKI, M.; KARDEL, I.; GIELCZEWSKI, M.; OKRUSZKO, T. Modelling of discharge, nitrate and phosphate loads from the Reda catchment to the Puck Lagoon using SWAT. Annals og Warsaw University of Life Sciences, v. 45, n. 2, p. 125-141, 2013. http://dx.doi.org/10.2478/ sggw-2013-0011.

MELO NETO, J. O.; SILVA, A. M.; MELLO, C. R.; MELLO JÚNIOR, A. V. Simulação hidrológica Escalar com o Modelo SWAT. Revista Brasileira de Recursos Hídricos, v. 19, n. 1, p. 177-188, 2014. http://dx.doi.org/10.21168/rbrh.v19n1.p177-188.

MERRIT'T, W. S.; LETCHER, R. A.; JAKEMAN, A. J. A review of erosion and sediment transport models. Environmental Modelling \& Software, v. 18, n. 8-9, p. 761-799, 2003. http://dx.doi.org/10.1016/ S1364-8152(03)00078-1.

MISHRA, A.; FROEBRICH, J.; GASSMAN, P. W. Evaluation of the SWAT model for assessing sediment control structures in a small watershed in India. Transactions of the $A S A B E$, v. 50, n. 2, p. 469-477, 2007. http://dx.doi.org/10.13031/2013.22637.

MONTEITH, J. L. Evaporation and environment. In: THE STATE AND MOVEMENT OF WATER IN LIVING ORGANISMS: SYMPOSIUM OF THE SOCIETY FOR EXPERIMENTAL BIOLOGY, 19., 1965, Cambridge. Proceedings... Cambridge: Cambridge University Press, 1965.

MONTGOMERY, D. C.; RUNGER, G. C. Applied statistics and probability for engineers. 3. ed. Hoboken: John Wiley \& Sons, 2003. $822 \mathrm{p}$.

MORIASI, D. N.; ARNOLD, J. G.; VAN LIEW, M. W.; BINGNER, R. L.; HARMEL, R. D.; VEITH, T. L. Model evaluation guidelines for systematic quantification of accuracy in watershed simulations. Transactions of the ASABE, v. 50, n. 3, p. 885-900, 2007. http:// dx.doi.org/10.13031/2013.23153.

MOUSSA, R.; CHAHINIAN, N.; BOCQUILLON, C. Distributed hydrological modelling of a Mediterranean mountainous catchmentmodel construction and multi-site validation. Journal of Hydrology, 
v. 337, n. 1-2, p. 35-51, 2007. http://dx.doi.org/10.1016/j. jhydrol.2007.01.028.

MULETA, M. K. Improving model performance using season-based evaluation. Journal of Hydrologic Engineering, v. 17, n. 1, p. 191-200, 2012. http://dx.doi.org/10.1061/(ASCE)HE.1943-5584.0000421.

NAIRAULA, R.; NORMAN, L. M.; MEIXNER, T.; CALLEGARY, J. B. Multi-gauge calibration for modeling the Semi-Arid Santa Cruz Watershed in Arizona-Mexico Border Area Using SWAT. Air, Soil and Water Research, v. 5, p. 41-57, 2012.

NASH, J. E.; SUTCLIFFE, J. V. River flow forecasting through conceptual models: part 1. A discussion of principles. Journal of Hydrology, v. 10, n. 3, p. 282-290, 1970. http://dx.doi. org/10.1016/0022-1694(70)90255-6.

NEITSCH, S. L.; ARNOLD, J. G.; KINIRY, J. R.; WILLIANS GRASSLAND, J. R. Soil and Water Assessment Tool theoretical documentation version 2009. Texas: Agricultural Research Service Blackland Research Center, Texas Agrilife Research, Texas A\&M University System, 2011.

NOOR, H.; VAFAKHAH, M.; TAHERIYOUN, M.; MOGHADDASI, $\mathrm{M}$. Comparison of single-site and multi-site based calibrations of SWAT in taleghan watershed. International Journal of Engineering., v. 27, n. 11, p. 1645-1652, 2014.

OVERTON, D. E. Muskingum flood routing of upland streamflow. Journal of Hydrology, v. 4, p. 185-200, 1966. http:// dx.doi.org/10.1016/0022-1694(66)90079-5.

PINIEWSKI, M.; OKRUSZKO, T. Multi-site calibration and validation of the hydrological component of SWAT in a large lowland catchment. In: ŚWIATEK, D.; OKRUSZKO, T. (Eds.). Modelling of bydrological processes in the narew catchment. Berlin: Springer, 2011. (Geoplanet: Earth and Planetary Sciences).

QI, C.; GRUNWALD, S. GIS-based hydrologic modeling in the sandusky watershed using SWAT. Transactions of the AS AE. American Society of Agricultural Engineers, v. 48, n. 1, p. 169-180, 2005. http:// dx.doi.org/10.13031/2013.17960.

SCHAAP, M. G.; LEIJ, F. J.; VAN GENUCHTEN, M. T. ROSETTA: a computer program for estimating soil hydraulic parameters with hierarchical pedotransfer functions. Journal of Hydrology, v. 251, n. 3-4, p. 163-179, 2001. http://dx.doi.org/10.1016/S00221694(01)00466-8.

SCHUOL, J.; ABBASPOUR, K. C. Calibration and uncertainty issues of a hydrological model (SWAT) applied to West Africa. Advances in Geosciences, v. 9, p. 137-143, 2006. http://dx.doi. org/10.5194/adgeo-9-137-2006.

SETTTE JUNIOR, C. R.; GEROMINI, M. P.; NAKAJIMA, N. Y. Quantificação da biomassa do tronco de Pinus Taeda em Plantios com diferentes idades na região de Rio Negrinho-SC. Biomassa \& Energia, v. 1, n. 4, p. 343-346, 2004.
SHEN, Z.; CHEN, L.; HONG, Q.; QIU, J.; XIE, H.; LIU, R. Assessment of nitrogen and phosphorus loads and causal factors from different land use and soil types in the Three Gorges Reservoir Area. The Science of the Total Environment, v. 454-455, p. 383-392, 2013. http://dx.doi.org/10.1016/j.scitotenv.2013.03.036. PMid:23562691.

SHRESTHA, M. K.; RECKNAGEL, F.; FRIZENSCHAF, J.; MEYER, W. Assessing SWAT models based on single and multi-site calibration forthe simulation of flow and nutrient loads in the semiarid Onkaparinga catchment in South Australia. Agricultural Water Management, v. 175, p. 61-71, 2016. http://dx.doi.org/10.1016/j. agwat.2016.02.009.

SIKORSKA, A. E.; RENARD, B. Calibrating a hydrological model in stage space to account for rating curve uncertainties: general framework and key challenges. Advances in Water Resources, v. 105, p. 51-66, 2017. http://dx.doi.org/10.1016/j.advwatres.2017.04.011.

SLOBODA, M.; SWAYNE, D. A. Autocalibration experiments using machine learning and high performance computing. Environmental Modelling \& Software, v. 40, p. 302-315, 2013. http:// dx.doi.org/10.1016/j.envsoft.2012.10.007.

SOARES, V. M. Aspectos físicos e químicos do complexo de represas Paraibuna-Paraitinga, São Paulo. 2011. 234 f. Dissertação (Mestrado em Ciências) - Instituto de Pesquisas Energéticas e Nucleares, Universidade de São Paulo, São Paulo, 2011.

SOUZA, R. M.; SANTOS, I. Estimativa da variabilidade espacial de vazões mínimas na bacia hidrográfica do Altíssimo Rio Negro, região sul-brasileira, com aplicação do modelo SWAT. O Espaço Geográfico em Análise, v. 28, p. 134-153, 2013.

STEDINGER, J. R.; VOGEL, R. M.; FOUFULA-GEORGIOU, E. Regionalization. In: MAIDMENT, D. R. (Ed.). Handbook of bydrology. New York: McGraw-Hill, 1992.

STRAHLER, A. N. Quantitative analysis of watershed geomorphology. Transactions - American Geophysical Union, v. 38, n. 6, p. 913-920, 1957. http://dx.doi.org/10.1029/TR038i006p00913.

THAMPI, S. G.; RANEESH, K. Y.; SURYA, T. V. Influence of Scale on SWAT model calibration for streamflow in a river basin in the humid tropics. Water Resources Management, v. 24, n. 15, p. 4567-4578, 2010. http://dx.doi.org/10.1007/s11269-010-9676-y.

TODINI, E. Hydrological catchment modelling: past, present and future. Hydrology and Earth System Sciences, v. 11, n. 1, p. 468-482, 2007. http://dx.doi.org/10.5194/hess-11-468-2007.

TUCCI, C. E. M. Processos hidrológicos e os impactos do uso do solo. In: TUCCI, C. E. M.; BRAGA, B. P. F. (Ed.). Clima e recursos bídricos no Brasil. Brasília: ABRH, 2003.

TUCCI, C. E. M.; COLLISCHONN, W. Ajuste multiobjetivo dos parâmetros de um modelo hidrológico. Revista Brasileira de Recursos 
Hidricos, v. 8, n. 3, p. 27-39, 2003. http://dx.doi.org/10.21168/ rbrh.v8n3.p27-39.

TUCCI, C. E. M.; MENDIONDO, E. M. Escalas hidrológicas I: conceitos. Revista Brasileira de Recursos Hidricos, v. 2, n. 1, p. 59-122, 1997. http://dx.doi.org/10.21168/rbrh.v2n1.p59-79.

TUPPAD, P.; KANNAN, N.; SRINIVASAN, R.; ROSSI, C. G.; ARNOLD, J. G. Simulation of agricultural management alternatives for watershed protection. Water Resources Management, v. 24, n. 12, p. 3115-3144, 2010. http://dx.doi.org/10.1007/s11269-010-9598-8.

USDA - U.S. DEPARTMENT OF AGRICULTURE. National Engineering Handbook: section 4: hydrology. Washington: Soil Conservation Service, 1972. chap. 4-10.

USEPA - U.S. ENVIRONMENTAL PROTECTION AGENCY. EPAQA/G-5M: guidance for quality assurance projectplans for modeling. Washington: U.S.EPA, Office of Environmental Information, 2002. p. 1-98. Report EPA/240/R-02/007.

USGS - UNITED SERVICE GEOLOGICAL SURVEY. Reston, 2013. Available from: <http://www.usgs.gov>. Access on: 21 june 2013.

VALE, M.; HOLMAN, I. P. Understanding the hydrological functioning of a shallow lake system within a coastal karstic aquifer in Wales, U.K. Journal of Hydrology, v. 376, n. 1-2, p. 285-294, 2009. http://dx.doi.org/10.1016/j.jhydrol.2009.07.041.

VAN GRIENSVEN, A.; MEIXNER, T.; GRUNWALD, S.; BISHOP, T.; DILUZIO, M.; SRINIVASAN, R. A global sensitivity analysis tool for the parameters of multi-variable catchment models. Journal of Hydrology, v. 324, n. 1-4, p. 10-23, 2006. http://dx.doi. org/10.1016/j.jhydrol.2005.09.008.

VAN LIEW, M. W.; GARBRECHT, J. D.; ARNOLD, J. G. Simulation of the impacts of flood-retarding structures on streamflow for a watershed in southwestern Oklahoma under dry, average, and wet climatic conditions. Journal of Soil and Water Conservation, v. 58, n. 6 , p. $340-348,2003$.

VIGIAK, O.; MALAGÓ, A.; BOURAOUI, F.; VANMAERCKE, M.; OBREJA, F.; POESEN, J.; HABERSACK, H.; FEHÉR, J.; GROŠELJ, S. Modelling sediment fluxes in the Danube River Basin with SWAT. The Science of the Total Environment, v. 599-600, p. 992-1012, 2017. http://dx.doi.org/10.1016/j.scitotenv.2017.04.236. PMid:28505891.

VIGIAK, O.; MALAGÓ, A.; BOURAOUI, F.; VANMAERCKE, M.; POESEN, J. Adapting SWAT hillslope erosion model to predict sediment concentrations and yields in large Basins. The Science of the Total Environment, v. 538, p. 855-875, 2015. http://dx.doi. org/10.1016/j.scitotenv.2015.08.095. PMid:26356993.

WAGNER, P. D.; KUMAR, S.; FIENER, P.; SCHNEIDER, $\mathrm{K}$. Hydrological modeling with SWAT in a monsoon-driven environment: experience from the Western Ghats, India. Transactions of the $A S A B E$, v. 54 , n. 5, p. 1783-1790, 2011. http://dx.doi. org/10.13031/2013.39846.

WATZLAWICK, L. F.; CALDEIRA, M. V. W.; VIERA, M.; SCHUMACHER, M. V.; GODINHO, T. O.; BALBINOT, R. Estoque de biomassa e carbono na Floresta Ombrófila Mista Montana Paraná. Scientia Forestalis, v. 40, n. 95, p. 353-362, 2012.

WILLIAMS, J. R. The EPIC model. In: SINGH, V. P. Computers models for watershed hydrology. Highlands Ranch: Water Resourses Publications, 1995. p. 909-1000.

WISCHMEIER, W. H.; SMITH, D. D. Predicting rainfall losses: a guide to conservation planning. Washington: U.S. Government Printing Office, 1978. (USDA Agricultural Handbook, 537).

WU, Y.; CHEN, J. An operation-based scheme for a multiyear and multipurpose reservoir to enhance macroscale hydrologic models. Journal of Hydrometeorology, v. 13, n. 1, p. 270-283, 2012. http:// dx.doi.org/10.1175/JHM-D-10-05028.1.

WU, Y.; LIU, S. Modeling of land use and reservoir effects on nonpoint source pollution in a highly agricultural basin. Journal of Environmental Monitoring, v. 14, n. 9, p. 2350-2361, 2012. http:// dx.doi.org/10.1039/c2em30278k. PMid:22790209.

XAVIER, A. C.; VETTTORAZZI, C. A.; CRUCIANI, D. E.; MACHADO, R. E. Efeito do nível de subdivisão em uma bacia hidrográfica na simulação da produção de sedimentos. Revista Brasileira de Recursos Hídricos, v. 12, n. 4, p. 49-58, 2007. http:// dx.doi.org/10.21168/rbrh.v12n4.p49-58.

XIE, H.; LIAN, Y. Uncertainty-based evaluation and comparison of SWAT and HSPF applications to the Illinois River Basin. Journal of Hydrology, v. 481, p. 119-131, 2013. http://dx.doi.org/10.1016/j. jhydrol.2012.12.027.

YANG, C. T. Sediment transport theory and practice. New York: McGraw-Hill, 1996.

YU, Z.; SCHWARTZ, F. W. Automated calibration applied to watershed-scale flow simulations. Hydrological Processes, v. 13, n. 19, p. 191-209, 1999. http://dx.doi.org/10.1002/(SICI)10991085(19990215)13:2<191::AID-HYP706>3.0.CO;2-N.

ZANIN, P. R.; BONUMA, N. B.; FRANCO, D. Comportamento hidrossedimentológico de bacia hidrográfica com reservatório. Revista Geociências, v. 36, n. 1, p. 185-203, 2017.

ZANIN, P. R.; BONUMA, N. B.; MINELLA, J. P. G. Determinação do fator topográfico em bacias hidrográficas. Revista Brasileira de Geomorfologia, v. 18, n. 1, p. 19-36, 2017. http://dx.doi.org/10.20502/ rbg.v18i1.1023.

ZEIGER, S. J.; HUBBART, J. A. A SWAT model validation of nested-scale contemporaneous stream flow, suspended sediment and nutrients from a multiple-land-use watershed of the central 
USA. The Science of the Total Environment, v. 572, p. 232-243, 2016. http://dx.doi.org/10.1016/j.scitotenv.2016.07.178. PMid:27501422.

ZHANG, D.; CHEN, X.; YAO, H.; LIN, B. Improved calibration scheme of SWAT by separating wet and dry seasons. Ecological Modelling, v. 301, p. 54-61, 2015a. http://dx.doi.org/10.1016/j. ecolmodel.2015.01.018.

ZHANG, J.; LI, Q.; GUO, B.; GONG, H. The comparative study of multi-site uncertainty evaluation method based on SWAT model. Hydrological Processes, v. 29, n. 13, p. 2994-3009, 2015 b. http://dx.doi.org/10.1002/hyp.10380.

ZHANG, N.; HE, H. M.; ZHANG, S. F.; JIANG, X. H.; XIA, Z. Q.; HUANG, F. Influence of reservoir operation in the Upper Reaches of the Yangtze River (China) on the inflow and outflow regime of the TGR-based on the improved SWAT model. Water Resources Management, v. 26, n. 3, p. 691-705, 2012. http://dx.doi. org/10.1007/s11269-011-9939-2.

ZHANG, X.; SRINIVASAN, R.; LIEW, M. V. Multi-site alibration of the SWAT model for hydrologic modeling. American Society of Agricultural and Biological Engineers, v. 51, n. 6, p. 2039-2049, 2008.

ZHANG, X.; SRINIVASAN, R.; LIEW, M. V. On the use of multi-algorithm, genetically adaptive multi-objective method for multi-site calibration of the SWAT model. Hydrological Processes, v. 24, n. 8, p. 955-969, 2010. http://dx.doi.org/10.1002/hyp.7528.
ZHANG, Y.; XIA, J.; CHEN, J.; ZHANG, M. Water quantity and quality optimization modeling of dams operation based on SWAT in Wenyu River catchment, China. Environmental Monitoring and Assessment, v. 173, n. 1-4, p. 409-430, 2011. http://dx.doi. org/10.1007/s10661-010-1396-5. PMid:20237841.

ZHANG, Y.; XIA, J.; SHAO, Q.; ZHAI, X. Water quantity and quality simulation by improved SWAT in highly regulated Huai River Basin of China. Stochastic Environmental Research and Risk Assessment, v. 27, n. 1, p. 11-27, 2013. http://dx.doi.org/10.1007/ s00477-011-0546-9.

\section{Authors contributions}

Paulo Rodrigo Zanin: Gathered and built the input data for the SWAT model, performed calibration procedures, built the graphs and figures, analyzed the results and wrote the article.

Nadia Bernardi Bonuma: Supervised this research during the masters period of the first author.

Claudia Weber Corseuil: Revised the article and suggested improvements in the text. 